\title{
A CARA DA ESCRAVIDÃO E A CARA DA LIBERDADE: HONRA E INFÂMIA (CORTE DO BRASIL, 1809-1833)
}

\author{
Roberto Guedes ${ }^{1}$ \\ Ana Paula Bôscaro ${ }^{2}$
}

$\mathrm{E}$

m Código de honra, o filósofo Antony Appiah nos conta que, em sua infância, um famoso cantor irlandês, Val Doonican, fazia sucesso com a música Walk tall, que pode ser traduzida como "Caminhar com Altivez". Na canção, a mãe do artista, quando este ainda era garoto, lhe dizia que acreditasse em si mesmo e, principalmente, olhasse o mundo nos olhos. Na sua maturidade, Appiah ainda se recorda de que em sua meninice sua mãe também lhe fazia as mesmas advertências. Para além de sugerir uma semelhança comportamental entre as mães, o filósofo afirma que aquela lição permaneceu com ele "por mais de quarenta anos certamente porque expressava com simplicidade um ideal de honra", visto que a psicologia da honra se liga profundamente à autoconfiança e ao "olhar o mundo nos olhos". Por isso, pessoas honradas têm ciência de merecerem respeito, de poderem andar com a cabeça erguida, "estufando o peito e endireitando as costas". ${ }^{3}$ De modo contrário, a humilhação encurva a coluna, faz baixar os olhos, diríamos mesmo que embarga a voz e nos leva a titubear com inseguras palavras.

1 Doutor em História pela Universidade Federal do Rio de Janeiro (UFRJ) e Professor Associado da Universidade Federal Rural do Rio de Janeiro (UFRRJ). robertoguedesferreira@gmail.com.

2 Doutoranda em História pela Universidade Federal de Juiz de Fora (UFJF). anapaulaboscaro@ gmail.com.

3 Kwame Anthony Appiah, O código de honra: como ocorrem as revoluções morais, São Paulo: Companhia das Letras, 2012, pp. 17-18. 
A honra da cara (rosto) também está na fala, vai da face aos dizeres em vários idiomas. Em axânti-twi, quando se faz algo desonroso diz-se que "Seu rosto caiu". Então, com a cara cheia de vergonha a pessoa baixa o olhar, mira o chão. Na língua twi, a palavra para honra é animuonyam, "que contém a raiz nim, que significa 'rosto"”. Já os chineses dizem "ficar sem cara", tal como os ingleses, franceses e alemães, que utilizam também a expressão "salvar a cara". Portanto, no Extremo Oriente, na Europa Ocidental e na África Ocidental, culturas e áreas muito diferentes, a língua associa a cara à honra ou à infâmia. ${ }^{4}$

Igualmente, o rosto expressa sentimentos, emoções morais como indignação e orgulho. Pela face sabemos o que os outros sentem e como nos veem, o que denota que a honra ou a vergonha se manifestam "quando estamos na presença de outrem". ${ }^{5}$ É o que chamamos de expressões faciais, de alegria, de tristeza etc. Com que cara, então, continuaremos este artigo depois de começá-lo com uma introdução baseada nas honradas ideias alheias? "A cara da escravidão e a cara da liberdade" trata de um assunto pouco arrostado. ${ }^{6}$ Literalmente, aborda as faces da escravidão e da liberdade no Sul-Sudeste do Brasil de inícios do século XIX, com base em passaportes e despachos de escravos emitidos pela Polícia da Corte entre os anos de 1809 e 1833. Associaremos os retratos falados dos rostos da escravidão e da liberdade à honra ou à ausência desta.

De início, lembramos que a reputação inscrita no rosto também guarda, em português, múltiplas e variadas expressões de linguagem. $\mathrm{Na}$ fisionomia, tudo o que se deixa ver é audível em nosso cotidiano vernáculo, pois o que a cara contém revela muito da personalidade e do modo como as pessoas percebem outras e são por elas julgadas. "Um homem de barba na cara se comportando como um moleque" sugere que a barba denota maturidade, ausente em imberbes e crianças; "tomou um tapa na cara”, mesmo com luva de pelica, é um dizer que denota uma

4 Appiah, $O$ código, pp. 17-18.

5 Appiah, $O$ código, pp. 17-18.

6 Isnara Pereira Ivo, Homens de caminho: trânsitos culturais, comércio e cores nos sertões da América portuguesa: século XVIII, Vitória da Conquista: Edições Uesb, 2012; Manolo Florentino, "No rastro de uma barba: a história atrás de passos apagados", in Susani Silveira Lemos França (org.), Questões que incomodam o historiador, São Paulo: Alameda, 2013, pp. 223-72. 
das maiores humilhações que se pode sofrer, e é muito difícil, até aos mais cristãos, dar a outra face; a cara ruboriza; fica-se vermelho ou verde de raiva; ter "vergonha na cara" significa comportar-se com condutas morais esperadas dos que são honrados, dignos, porque agir diferente é para gente de mau cara-c-ter (caráter), "cara de pau". "Cara de pau" é ambivalente, alude à gente indigna e desonesta, mas também aos sem timidez, até audazes, àqueles que "metem a cara", vão "com a cara e a coragem", mas, mesmo nessa ambivalência, a face revela o que a pessoa é. Por outro lado, o "ficar com a cara no chão", "ficar sem cara" ou com "cara de bunda", como frequentemente ouvimos quando se maldiz alguém, é muito semelhante ao "ficar sem cara" dos chineses ou dos europeus ocidentais, e mais semelhante ainda ao "seu rosto caiu" em axânti-twi, língua que associa a honra ao rosto, à cara. Em bom brasileiro, ir ou não com "a cara de" alguém é questão pessoal, mas também aí o afeto se sente no rosto, mesmo que, como reza o dito popular, "quem vê cara não vê coração".

Dir-se-á, talvez, que as aparências enganam, mas o oposto disso ocorre quando se ouve "Não tá vendo, tá bem aí na tua cara", "tá bem debaixo do teu nariz", "tá na cara". Assim, tudo que "tá na cara" e não se compreendeu ou não se percebeu revela miopia intelectual, incapacidade cognitiva, boçalidade. No passado escravista brasileiro, boçal significava "rude", "sem arte", e havia os de "entendimento boçal", não "cultivado". Era esse o adjetivo usado para aludir a quem não falava "ainda a língua do país estrangeiro" no qual se encontrava. O termo reportava-se, em geral, aos escravos "pretos, opondo-os aos ladinos". ${ }^{7}$ Apesar de ter nome cristão, em 1831, João Rebolo, 14 anos de idade, olhos grandes e rosto redondo, foi considerado "boçal" no despacho de sua venda. Aos olhos de um funcionário da Polícia, sua cara era autoevidente e revelava o que ele parecia ser: boçal. Esta face do cativo foi caracterizada em uma sociedade de antigo regime, na qual as aparências não enganavam, eram essência.

As pessoas deviam aparentar o que eram ou o que deveriam ser; ser e parecer ser eram normatizados e marcavam lugares sociais, status,

7 "Boçal”, in Antonio de Moraes Silva, Dicionário da língua portuguesa, 2a ed. (Lisboa: Tipografia Lacerdina, 1813). 
formas de tratamento etc. ${ }^{8}$ Então, em termos de parecer, não era possível ter duas caras, sobretudo naquele mundo das exterioridades que se imbricou na escravidão no Rio de Janeiro de princípios do século XIX, cidade que foi transformada com a vinda da corte portuguesa em $1808 .{ }^{9}$ O viajante inglês John Luccock, que esteve na cidade no início do oitocentos, foi enfático no que se refere à autorrepresentação: "Tinha-se isso tornado no principal interesse dos brasileiros e era muito menos difícil conquistar alguém a notoriedade pública pela sua indiscutível fortuna do que pela representação que sustentava e a figura que fazia". ${ }^{10}$

Perante reelaborações de antigo regime nos trópicos, ${ }^{11}$ derivadas da escravidão que crescia a passos largos, será que livres, forros (ambos senhores em potencial) e escravos aparentavam faces diferentes na corte escravista do Brasil, fortemente impactada pela chegada de milhares e milhares de cativos vindos via tráfico atlântico? Havia estigma na escravidão e honra na liberdade a ponto de levar a diferentes percepções/ classificações faciais? Para cada um dos segmentos jurídicos da sociedade (livres, forros e escravos) havia diferentes caracterizações de traços sociofisionômicos? Ou tudo isso não tem nada a ver e a distinção e a percepção dos semblantes dependiam da naturalidade e da origem? Seriam aspectos mais relacionados a condições econômicas, ocupacionais, faixa etária, entre outros? Que fatores, enfim, davam rosto aos indivíduos? Para responder às perguntas, analisaremos as descrições corporais

8 Daniel Roche, A cultura das aparências: uma história da indumentária (séculos XVII XVIII), São Paulo: Editora Senac, 2007, p. 20; António Manoel Hespanha, Imbecillitas: as bem-aventuranças da inferioridade nas sociedades de Antigo Regime, São Paulo: Annablume, 2010. Tais aspectos se combinavam bem com a escravidão. Cf. Eduardo Paiva, Escravidão e universo cultural na colônia: Minas Gerais, 1716-1789, Belo Horizonte: Editora UFMG, 2001; Sílvia Lara, Fragmentos setecentistas: escravidão, cultura e poder na América portuguesa, São Paulo: Companhia das Letras, 2007.

9 Gilberto Freyre, Sobrados e mocambos: a decadência do patriarcado rural e desenvolvimento do urbano, 13a ed., Rio de Janeiro: Record, 2002; Jurandir Malerba, A corte no exílio; civilização e poder no Brasil às vésperas da Independência (1808-1821), São Paulo: Companhia das Letras, 2000.

10 John Luccock, Notas sobre o Rio de Janeiro e partes meridionais do Brasil, São Paulo: Edusp, Belo Horizonte: Itatiaia, 1975, p. 364.

11 João Fragoso, Maria Gouvêa e Fernand Bicalho (orgs.), $O$ antigo regime nos trópicos: a dinâmica imperial portuguesa, Rio de Janeiro: Civilização Brasileira, 2001; João Fragoso e Nuno Monteiro (orgs.), Um reino e suas repúblicas no Atlântico: comunicações políticas entre Portugal, Brasil e Angola nos séculos XVII e XVIII, Rio de Janeiro: Civilização Brasileira, 2017. 
feitas pela Polícia presentes nos códices 421 e 425 (passaportes), 390 e 424 (despachos de escravos) e 411 (termos de fiança). ${ }^{12}$

Criada em 5 de abril de 1808, a Polícia da Corte do Rio de Janeiro exercia poderes judiciais e era da sua alçada a manter ordem e a salubridade, zelar pela conduta dos habitantes e pelo "bem-viver", ${ }^{13}$ bem como controlar a circulação de mercadorias e pessoas, inclusive escravos etc. ${ }^{14}$ A palavra Polícia significava "o governo e a administração interna da República". ${ }^{15}$ Para aferir o fluxo das pessoas que partiam da cidade do Rio de Janeiro, a administração se valeu de despachos de escravos e passaportes, documentos que também atestam o enorme comércio interno no eixo Sul-Sudeste do Brasil durante as três primeiras décadas

12 Grande parte da documentação sobre a circulação de pessoas, emitida pela Intendência Geral de Polícia da Corte, foi sistematizada em bancos de dados formados por 43 volumes dos códices 390, 411, 421, 424 e 425 da Coleção Polícia da Corte (doravante CP), do Arquivo Nacional do Rio de Janeiro (doravante ANRJ). Supervisionado por João Fragoso e coordenado por Roberto Guedes, no âmbito do então Laboratório de Pesquisa em História Social da UFRJ, a empreitada foi realizada em 1999-2001 a partir da proposta do Instituto de Pesquisa Econômica Aplicada (Ipea), presidido na ocasião por Roberto B. Martins. Precisamente, os códices 421 e 425 podem ser caracterizados como de passaportes, e o 390 e 424 como de despachos. O códice 390 não contém descrições físicas dos viajantes, salvo em certos casos de escravos no volume 1 . O códice 411, que se intitula "Termos de fiança, ajuste, obrigação, lanço etc.", sem precisão em informações sobre remessas de cativos, e sem descrição física. Não foi incluído na análise, exceto o volume 1 que alude a traços físicos dos escravos. Vide: João Fragoso e Roberto Guedes, “Alegrias e artimanhas de uma fonte seriada: os códices 390, 421, 424 e 425: despachos de escravos e passaportes da Intendência de Polícia da Corte, 1819-1833", in Tarcísio Botelho (org.), História quantitativa e serial no Brasil: um balanço (São João del-Rei: Anpuh-MG, 2001); João Fragoso e Roberto Guedes, "Tráfico de escravos, mercadores e fianças: dois bancos de dados (despachos de escravos, passaportes e licenças): Códices 390, 411, 419, 421, 424, 425, 1000 e 1002" (Relatório de Pesquisa, Instituto de Pesquisa Econômica Aplicada, 2001).

13 Termos de Bem Viver, 2 v., ANRJ-CP, Códice 410; Roberto Guedes, "Autonomia escrava e (des)governo senhorial na cidade do Rio de Janeiro da primeira metade do século XIX", in Manolo Florentino (org.), Tráfico, cativeiro e liberdade (Rio de Janeiro, séculos XVII-XIX) (Rio de Janeiro: Civilização Brasileira, 2005), pp. 229-83.

14 Sobre Polícia, ver: Gizlene Neder, A polícia na Corte e no Distrito Federal, Rio de Janeiro: PUC-Rio, 1981; Leila Mezan Algranti, O feitor ausente: estudos sobre a escravidão urbana no Rio de Janeiro (1808-1822), Petrópolis: Vozes, 1988; Thomas Holloway, Polícia no Rio de Janeiro: repressão e resistência numa cidade do século XIX, Rio de Janeiro: FGV, 1997; Marcos Luiz Bretas, “A polícia carioca no Império”, Estudos Históricos, v. 12, n. 22 (1998), pp. 219-34, p. 122. Para um bom balanço: Marcos Luiz Bretas e André Rosenberg, "A história da polícia no Brasil: balanço e perspectivas", Topoi, v. 14, n. 26 (2013), pp. 162-73.

15 "Polícia", in Silva, Dicionário. Ver ainda Catarina Madeira Santos, "Um Governo polido para Angola: Reconfigurar dispositivos de domínio (1750-c.1800)" (Tese de Doutorado, Universidade de Lisboa, 2006). 
do Oitocentos, sobretudo a redistribuição de "escravos novos" (africanos) a partir da cidade, então o ponto nodal do eixo mais dinâmico da economia colonial/imperial. Despachos e passaportes foram, em suma, criados para governar.

O passaporte era uma licença "por escrito que dá a pessoa, a quem isto incumbe, ao que quer sair para fora do reino ou cidade". ${ }^{16}$ Esses documentos informam a partida de livres ou escravos que encabeçavam tropas, chefes de tropas, acompanhados ou não de outros membros da comitiva de viagem, sendo-nos possível observar também a presença de alguns escravos despachados (comercializados). Outro tipo de viagem abrangida pelos passaportes era a que faziam homens e mulheres solitários ou em companhia de parentes e/ou cativos domésticos. Os passaportes eram emitidos para todos aqueles que, saindo do Rio de Janeiro, preferencialmente se iam para Minas Gerais, São Paulo, Espírito Santo, Rio Grande de São Pedro, municípios da capitania fluminense, entre outras tantas localidades situadas no interior do que hoje chamamos de Sul-Sudeste; para a Bahia ${ }^{17}$; e, às vezes, até mesmo para a Europa, América não portuguesa e África. Em não poucos casos, despachos de escravos, que serão detalhados mais adiante, e passaportes podiam se combinar em um mesmo registro.

Pela abrangência geográfica e de pessoas em trânsito, os documentos nos propiciam uma análise da caracterização da sociedade escravista a partir da Polícia, uma vez que há dados pessoais e sociais sobre viajantes: nome, sexo, idade, ofício, título, qualidade de cor, conjugada ou não à condição jurídica (pardo, trigueiro, preto, preto forro, pardo forro

16 "Passaporte", in Silva, Dicionário.

17 Fragoso e Guedes, "Alegrias e artimanhas"; "Tráfico de escravos"; Gabriel Berute, "O comércio de africanos ladinos e crioulos: vila do Rio Grande (1812-1822)", História Unisinos, v. 10 (2006), pp. 259-72; "Rio Grande de São Pedro do Sul, c. 1790-c. 1830: tráfico negreiro e conjunturas atlânticas", in Regina Célia Xavier Lima (org.), Escravidão e liberdade: temas, problemas e perspectivas de análise (São Paulo: Alameda, 2012), pp. 207-228; Alexandre Vieira Ribeiro, "O comércio das almas e a obtenção de prestígio social: traficantes de escravos na Bahia ao longo do século XVIII", Locus, v. 12 (2006), pp. 9-27; "O comércio de escravos e a elite baiana no período colonial", in João Fragoso, Carla Carvalho de Almeida e Antônio Carlos Jucá de Sampaio (orgs.). Conquistadores e negociantes: histórias de elites no Antigo Regime nos trópicos: América Lusa, séculos XVI a XVIII (Rio de Janeiro: Civilização Brasileira, 2007), pp. 311-35; Ivo, Homens de caminho, cap. 4. 
etc.), ${ }^{18}$ estado conjugal, moradia, naturalidade, destino e data de partida. Há também características corporais dos viageiros que se iam do Rio de Janeiro: altura, peso, formato do rosto, formato e cor dos olhos, cabelo, barba. Para os cativos, além dos nomes de seus senhores, pode haver dados sobre a naturalidade crioula, ou africana (Angola, Congo etc.), e até mesmo sinais na face e marcas corporais. Evidentemente, todas as informações variam de um registro a outro, e a própria frequência de cada tipo de informação revela o que o governo avaliava imprescindível para dar cara à sua gente, fazer-lhe o retrato falado. Passaportes são dos raros documentos que classificam as pessoas fisicamente, incluindo os escravos. ${ }^{19}$ Bons exemplos destes documentos são, respectivamente, os encabeçados por Maximiano José das Neves, de outubro de 1809, e por Francisca de Jesus, de setembro do mesmo ano:

Maximiano José das Neves, natural de Lisboa e morador nesta
cidade, de idade de 20 anos, que vive de negócio, solteiro, esta-
tura ordinária e rosto comprido, e muito bexigoso, bastante bar-
ba, sobrancelhas pretas, parte para Ilha de Santa Catarina, e leva
seu escravo de nome Joaquim Angola, estatura ordinária, rosto

18 Empregamos o termo cor ou qualidade de cor para aludir a pardos, pretos, cabras, mulatos, morenos, trigueiros, expressões, salvo trigueiros e morenos, que podiam, tal como crioulos, estar acompanhadas de condição jurídica (livre, forra e escrava): pardo livre, pardo forro/ liberto, pardo escravo etc. Mas, mesmo as que estavam desacompanhadas de condição jurídica, não significavam, necessariamente, o que hoje chamamos "de cor". Crioulo, no mais das vezes alude à naturalidade brasileira. Já morenos e trigueiros, expressões menos frequentes na documentação que consultamos, aludem ao que designamos por cor. Assim, por exemplo, 251 homens foram descritos como "homem pardo", mas ao mesmo tempo de rosto "trigueiro", comprido ou redondo. Um deles foi Jacinto de Azeredo Coutinho (ANRJ-CP, cód. 421, 3, fl. 208). Sobre o assunto das qualidades, ver Eduardo França Paiva, Dar nome ao novo: uma história lexical da Ibero-América, entre os séculos XVI e XVIII (as dinâmicas de mestiçagens e o mundo do trabalho), Belo Horizonte: Autêntica, 2015; Eduardo França Paiva, Manuel F. Fernández Chaves e Rafael M. Pérez García (orgs.), De que estamos falando? Antigos conceitos e modernos anacronismos: escravidão e mestiçagens, Rio de Janeiro: Garamond, 2016; Isnara Pereira Ivo e Eduardo França Paiva, Dinâmicas de mestiçagens no mundo moderno: sociedades, culturas e trabalho, Vitória da Conquista: Edições Uesb, 2016.

19 Até mesmo em inventários post-mortem são raras as descrições de características físicas dos escravos. Estudos sobre o assunto com base em registros de batismo são os de Moacir Rodrigo de Castro Maia, "De reino traficante a povo traficado: a diáspora dos courás do Golfo do Benim para as minas de ouro da América Portuguesa (1715-1760)" (Tese de Doutorado, Universidade Federal do Rio de Janeiro, 2013), p. 163 e seguintes. Ver também: Adriano Parreira, "Quatro livros de registro de escravos, Angola (1855). Ambriz, Golungo Alto, Libongo, Tala Mugongo", Africana Studia, n. 15 (2010), p. 135. Jornais também são propícios a este tipo de análise. 
comprido sem barba, sobrancelhas delgadas, e leva mais 14 escravos novos no Bergantim Miliciano, Mestre José Antônio da Costa, dos quais apresentou a competente fiança como consta da guia que apresentou, foi reconhecido por Aleixo Paes Sardinha. ${ }^{20}$

Francisca de Jesus, mulher crioula, natural e moradora em Macacu, distrito desta cidade, de idade de 40 anos, solteira, estatura ordinária, rosto comprido e bexigoso, sobrancelhas delgadas, parte para Minas de Cantagalo pela Cachoeira, com quatro filhos de nomes Joaquim da Silva, homem pardo de idade de vinte e um anos, que vive do oficio de carpinteiro, estatura ordinária, rosto comprido, com princípio de barba, sobrancelhas delgadas, Laureano crioulo, estatura ordinária, de idade de 16 anos, rosto comprido, olhos grandes, sobrancelhas delgadas, Claudina Francisca de Jesus, parda de idade de quinze anos, estatura ordinária, rosto comprido, sobrancelhas delgadas, lábios grossos, e Manoel, de idade de dez anos, rosto comprido, sobrancelhas delgadas, nariz rombo. E leva mais Inácia de Jesus, sua irmã, de idade de trinta e seis anos, estatura mais da ordinária, rosto comprido, lábios grossos, sobrancelhas delgadas, nariz pouco chato, com quatro filhos, Firmina de idade de onze anos, rosto comprido, sobrancelhas delgadas, nariz afilado, Luisa, de idade de dez anos, rosto comprido sobrancelhas delgadas, olhos pretos, Mateus, de oito anos, rosto comprido, sobrancelhas delgadas, e Angélica Felisberta, de idade de vinte anos, rosto comprido, sobrancelhas delgadas, nariz afilado, apresentou folha corrida e foram reconhecidos por Antônio de Oliveira Pinto. ${ }^{21}$

O destino do português solteiro, barbudo e de sobrancelhas pretas, Maximiano, contrastava com o de Francisca, crioula de rosto comprido e sobrancelhas delgadas, que viaja acompanhada de filhos, irmã e sobrinhos. Enquanto o tráfico atlântico de cativos ia a passos largos e se iniciavam as atividades da Intendência de Polícia da Corte, Maximiano aproveitou os bons ventos da atividade e partiu com seu escravo cristão

20 ANRJ-CP, Códice 421, v. 1, fl. 175.

21 ANRJ-CP, Códice 421, v. 1, fl. 50. 
para mercadejar cativos novos (africanos) no Sul, via comércio de cabotagem. Francisca crioula e sua parentela deviam estar indo se estabelecer numa área rural do Rio de Janeiro, talvez atraídos pela expansão cafeeira no município de Cantagalo, no vale do Paraíba do Sul fluminense. Vidas, experiências e destinos muito distintos contemplados nos passaportes atestam que a sociedade escravista abrangia muitas faces. Como veremos, a barba de Maximiano não era para todos e guardava estreita relação com o ser livre. Ter barba não era atributo das mulheres, certamente, mas nem todo homem tinha a honra de exibir bastante barba na cara. A propósito, apesar de adulto, o pardo José, na condição de filho, tinha apenas princípio de barba. Tampouco a usava o escravo de Maximiano José das Neves, de "estatura ordinária, rosto comprido sem barba".

Francisca crioula é, até certo ponto, uma exceção, posto que apenas $531(1,6 \%)$ mulheres encabeçaram as viagens ou foram descritas sozinhas nos 33.486 passaportes sobre chefes de tropa que nos servem de base. Advertimos, igualmente, que contaremos as descrições por viagem, não por pessoas que, não raro, eram vistas de modos diferentes em cada partida, inclusive em suas qualidades de cor, frequentemente omitidas. Por exemplo, Albino José da Silva fora duas vezes para Resende, em outubro de 1814 e fevereiro de 1815. Na primeira viagem, era "homem pardo", de 35 anos, estatura ordinária e rosto comprido; ${ }^{22}$ na segunda, esse homem natural de Resende, sem alusão à sua qualidade de cor/condição, amadurecera cinco anos e, ainda de rosto comprido, foi julgado com baixa estatura. ${ }^{23}$ Silenciou-se sobre sua qualidade de pardo no segundo registro, ou seja, sua ascendência escrava não foi assinalada, o que não era nada de somenos numa sociedade escravista, o mesmo se observava nos caminhos da Bahia setecentista. ${ }^{24}$

O rosto e o que ele deixava ver também se transmutavam de acordo com o que os olhos alheios viam. Em dezembro de 1822, moradora e natural do Rio Grande, Gertrudes Luiza de Andrade possuía 26 anos de idade. Fisicamente, era de estatura ordinária, "clara" e com uma "ci-

23 ANRJ-CP, Códice 421, v. 5, fl. 68.

24 Ivo, Homens de caminho, cap. 4. 
catriz na testa", ${ }^{25}$ mas, em agosto de 1823, indo-se para Porto Alegre, onde residia, ainda aos 26 anos de idade, a natural de Iguaçu, Gertrudes Luiza de Andrade, era de rosto redondo e olhos azuis, mas a cicatriz saiu da testa e foi para a "face esquerda". ${ }^{26}$ Já o padre Alexandre Gomes de Azevedo, natural da Corte, ao viajar para Santos em 1822, apresentava estatura ordinária e bastante barba em seu rosto redondo. ${ }^{27}$ Foi para o mesmo local em 1823, ainda com bastante barba, mas tornou-se um homem "cheio de corpo" e de rosto comprido. ${ }^{28}$ Entre um registro e outro, ele engordou e afinou o rosto, ou foi engordado e afinado pelo olhar dos responsáveis em descrevê-lo.

Como se nota, pessoas mudavam de aparência conforme eram percebidas por outras. Daí quantificarmos caracterizações de cada viagem, não as pessoas mutantes. Outra ressalva sobre a documentação diz respeito aos tipos de escravos, quer em passaportes, quer em despachos. Havia os (1) "novos", africanos sem nome cristão, recém-chegados ao Rio de Janeiro, e que formavam a imensa maioria; os (2) "ladinos", já com nome cristão, ou assim por nós caracterizados por terem sido batizados; os (3) "escravos que [Fulano] trouxe", isto é, os cativos que acompanhavam as tropas, geralmente vindas e de regresso a Minas Gerais. Quando o responsável pela tropa era também um mancípio, os acompanhantes de igual condição jurídica eram chamados de "parceiros". E, por fim, havia (4) crias e (5) marinheiros. Para o período de 1809 a 1833, os totais são os seguintes: novos, 169.110; ladinos, 19.603; escravos que [Fulano] trouxe, 49.450; crias, 539; e marinheiros, 2.462. ${ }^{29}$

Os despachos de escravos apresentam também autorizações e nomes, sem descrição física de terceiros (abonadores, fiadores, reconhecedores), e normalmente eram documentos assinados por estes e/ ou por funcionários da Polícia. Porém, os despachos são menos ricos

ANRJ-CP, Códice 421, v. 8, fl. 40.

26 ANRJ-CP, Códice 421, v. 8, fl. 153.

27 ANRJ-CP, Códice 421, v. 18, fl. 176v.

28 ANRJ-CP, Códice 421, v. 18, fl. 17.

29 Fragoso e Guedes, "Alegrias e artimanhas"; "Tráfico de escravos". Sobre parceiros, ver: Robert W. Slenes, Na senzala uma flor: esperanças e recordações na formação da família escrava: Brasil, Sudeste, Século XIX, Rio de Janeiro: Nova Fronteira, 1999, p. 51; Mary Karasch, Slave Life in Rio do Janeiro, 1808-1850, Princeton: Princeton University Press, 1987, cap. 1. 
em detalhes do que os passaportes. Na maior parte das vezes, quando se trata de remessas de escravos novos, não apresentam, salvo o nome do despachante, nada sobre aspectos sociais e físicos dos viajantes. No que diz respeito ao condutor da tropa e/ou responsável pela remessa de escravos, não é possível saber precisamente se o despachante partia junto com os cativos ou apenas os remetia. ${ }^{30}$

Esses registros permitem-nos verificar ainda a existência de marcas corporais, mas não as analisaremos. As marcas, mencionadas apenas em despachos de "escravos novos", eram desenhadas à margem das folhas dos códices e podiam ser coletivas ou uma para cada mancípio. Elas assinalavam a posse de senhores e/ou de comerciantes, ${ }^{31}$ mas não desprezamos a possibilidade de que fossem carimbos oriundos de sociedades africanas de origem, sobretudo da África Central atlântica, de onde veio a imensa maioria dos cativos desembarcados no Rio de Janeiro. ${ }^{32}$ "Carimbo" é um termo não dicionarizado por Morais e Silva, deriva da palavra kirimbu, em quimbundo, que quer dizer marca. Marcar alguém era atestar a condição de escravo em sociedades do Reino de Angola. ${ }^{33}$ Os escravos novos despachados pela Polícia podiam trazer marcas, mas para eles não havia descrição de atributos físicos. Por isso não serão abordados.

A ausência de informações sobre viajantes que encabeçavam as tropas nos despachos de escravos, ou sobre o responsável pela remessa, e mormente para os escravos novos, ${ }^{34}$ é compensada nos passaportes

30 Fragoso e Guedes, "Alegrias e artimanhas"; "Tráfico de escravos”.

31 Luciano Figueiredo, Marcas de escravos: listas de escravos emancipados vindos a bordo de navios negreiros (1839-1841), Rio de Janeiro: Publicações Históricas, 1990; Fragoso e Guedes, "Tráfico de escravos".

32 Manolo Florentino, Em costas negras: uma história do tráfico atlântico de escravos entre a África e o Rio de Janeiro: séculos XVIII e XIX. Rio de Janeiro: Arquivo Nacional, 1995; Joseph C. Miller, Way of Death: Merchant Capitalism and the Angolan Slave Trade: 1730-1830, Madison: Wisconsin University Press, 1988; Roquinaldo Ferreira, "Dos Sertões ao Atlântico. Rio de Janeiro". (Dissertação de Mestrado, Universidade Federal do Rio de Janeiro, 1997); Mariana Candido, An African slaving port and the Atlantic world: Benguela and Its Hinterland, Nova York: Cambridge University Press, 2013.

33 Catarina Madeira Santos, "Les mots e les normes juridiques de l'esclavage dans la colonie portugaise d'Angola aux XVIIe et XVIIIe siècles (les mucanos comme jugmentes de liberté", Brésil(s): Cahiers du Brésil Contemporain, n. 1 (2012), pp. 139, 144.

34 Por exemplo, "Termo que assina Francisco Antônio da Gama de como recebeu o atestado com que Valentim Gomes despachou para Minas dez escravos novos com as marcas à margem, 
pela caracterização social e física dos viajantes, como vimos nos exemplos, mas igualmente em despachos de escravos ladinos, como a seguir:

José dos Santos Almeida remete para São Paulo, pela vila de Santos, no Bergantim Destino, de que é mestre ele dito Almeida, oitenta e nove escravos, a saber, desses quatro ladinos de nomes Felícia Rebolo, de estatura ordinária, rosto comprido, lábios grossos, sobrancelhas delgadas, Rosa Mogumbe, de estatura ordinária, rosto comprido, lábios delgados, sobrancelhas finas, nariz rombo, com um filho de nome Graciano, molequinho de dez anos, rosto comprido, sobrancelhas delgadas, e Felipa crioula, estatura ordinária, rosto comprido, lábios grossos, sobrancelhas delgadas, dos quais pagou os reais direitos como consta da guia que apresentou, e assinou este termo Manoel Joaquim Ribeiro, e João Joaquim Marques de Castro morador em casa do dito Ribeiro. ${ }^{35}$

Nos casos em que há descrição física dos escravos, como Rosa Mogumbe, tais informações são de tipo similar à do cativo de Maximiano José das Neves. Apesar da diferença existente entre despachos de escravos e passaportes, importa-nos frisar, como dissemos, que despachar/remeter escravos para fora do Rio de Janeiro não foi uma atribuição exclusiva dos despachos. A despeito do governo que exercia sobre a saída de mercadorias da capitania/província carioca, a Polícia da Corte nem sempre tomou o cuidado de delinear um documento específico para os despachos, como é o caso dos códices 421 e 425 . No exemplo anterior, vê-se que, infelizmente, não há caracterização física dos escravos novos. Somente a partir da Lei de 1831, para burlá-la, é que se realiza de modo mais sistemático a avaliação corporal dos escravos, pois o grosso deles se "ladinizou" de repente. Até então, os escravos novos eram a imensa maioria. ${ }^{36}$

assinado por Francisco Clemente Pinto", ANRJ-CP, Códice 421, v. 2, fl. 175.

35

36

Um bom exemplo de como a Lei de 1831 foi burlada se encontra no volume 7 do códice 424 . Esse volume abrange o período de 20 de junho de 1831 a 28 de janeiro de 1832 . Nele há 1.111 registros, dos quais $1.077 \mathrm{se} \mathrm{referem} \mathrm{a} \mathrm{ladinos} \mathrm{que} \mathrm{foram} \mathrm{despachados,} \mathrm{e} \mathrm{apenas} 15$ assinalam a presença de escravos novos, dois dos quais estão acompanhados de ladinos. Sobre a Lei de 1831, ver, entre outros, Beatriz Mamigonian, Africanos livres: a abolição do tráfico de escravos no Brasil, São Paulo: Companhia das Letras, 2017. 
Apesar da ausência de informações sobre o corpo da maioria dos escravos, os despachos de cativos são um dos poucos documentos que as contêm; nem mesmo os inventários post-mortem primam por tais caracterizações, posto que geralmente se reportam a nome, idade, aptidões ocupacionais, estado de saúde e preço. ${ }^{37}$ Resta-nos, adiante, cruzar os atributos corporais dos cativos com fontes iconográficas.

Mas, afinal de contas, o que a descrição física tem a ver com escravidão, honra e barba? Com exceções, certa historiografia da escravidão, principalmente a que opera com a ideia de "raça" associada ao fenótipo e como um marcador indelével das hierarquias sociais, nem sempre se dá conta de que lidamos com uma sociedade escravista na qual as classificações sociais, inclusive as corporais, são indissociáveis da escravidão. Apartar a suposta ideia de raça (qualquer que seja ela) de uma sociedade escravista, ${ }^{38}$ e tomá-la como conceito explicativo maior, ou único, é não ver o que está na cara. A perspectiva aqui é diferente. Parte-se do conceito de sociedade escravista para entender os sinais nas faces das pessoas que viviam naquela sociedade. Isto significa dizer que a escravidão cria e recria expressões que pautam hierarquias sociais, fornece parâmetros de classificação e conceitos, não o contrário. Ao menos, não se entende os segundos sem a primeira, inclusive no quesito qualidade de cor. ${ }^{39}$

37 Roberto Guedes, "Na pia batismal: família e compadrio entre escravos na freguesia de São José no Rio de Janeiro" (Dissertação de Mestrado, Universidade Federal Fluminense, 2000); Egressos do cativeiro, trabalho, familia, aliança e mobilidade social (Porto Feliz, São Paulo, c.1798-c.1850), Rio de Janeiro: Mauad, 2008.

38 Moses Finley, Escravidão antiga e ideologia moderna, Rio de Janeiro: Graal, 1991; Stuart Schwartz, Segredos internos: engenhos e escravos na sociedade colonial, 1550-1835, São Paulo: Companhia das Letras, 1988, cap. 9.

39 Peter L. Eisenberg, Homens esquecidos: escravos e trabalhadores livres no Brasil: séculos XVIII e XIX, Campinas: Editora Unicamp, 1989, pp. 269-270; Sheila de Castro Faria, "Sinhás pretas, damas mercadoras: as pretas minas nas cidades do Rio de Janeiro e de São João Del Rey (1750-1850)" (Tese para concurso de Professor Titular de História do Brasil, Universidade Federal Fluminense, 2005), p. 76; Cacilda Machado, A trama das vontades: negros, pardos e brancos na construção da hierarquia social do Brasil escravista, Rio de Janeiro: Apicuri, 2009; Guedes, Egressos do cativeiro, caps. 2 e 5; Marcelo Santos Matheus, "A produção da diferença: escravidão e desigualdade social ao Sul do Império Brasileiro (Bagé, 1820-1870) (Tese de Doutorado, Universidade Federal do Rio de Janeiro, 2016), cap. 5; Júlia Aguiar e Roberto Guedes, "Pardos e pardos forros: agentes da escravidão e da mestiçagem (São Gonçalo do Amarante, Rio de Janeiro, século XVIII)", in Roberto Guedes e João Fragoso (orgs.), História social em registros paroquiais (Sul-Sudeste do Brasil, séculos XVIII-XIX) (Rio de Janeiro: Mauad X, 2016), pp. 87-120; Roberto Guedes, "Senhoras pretas forras, seus escravos negros, seus forros mulatos e parentes sem qualidades de cor: uma história de racismo ou de 
O que as fontes dizem sobre a aparência das pessoas que, retirando-se da Corte do Rio de Janeiro, andavam pelo eixo econômico principal da América Portuguesa, depois império do Brasil? Para responder, segmentamos a análise da descrição física e social conforme o lugar ocupado pelos viajantes na tropa/despacho. Desprezando os acompanhantes, analisaremos os cabeças de tropa (o primeiro viajante a ser enunciado) e os escravos despachados e/ou comercializados. A amostragem é composta por 33.486 descrições de cabeças de tropa, incluindo mancípios, e 8.839 registros de cativos despachados. Com intuito de perceber mudanças e permanências, dividimos o período em duas fases: 1809 a 1821 e 1822 a 1833. Ademais, o ano de 1822 também assinala a Independência do Brasil, logo, possíveis mudanças na forma de o governo classificar suas gentes.

\section{As caras dos chefes/cabeças de tropa}

Primeiro, aclaremos que as Figuras 1 e 2 apresentam gráficos com a frequência de informações sociais e corporais sobre os cabeças de tropa registradas pelos funcionários do governo e administração da República. Sobressai que as informações sociais mais relevantes eram naturalidade, moradia e ocupação/título, em ambas as fases. Qualidade de cor era o quarto tipo de aspecto que mais preocupava a Polícia, mas nem de longe se equipara aos três primeiros, sobretudo à moradia e à naturalidade, e era seguido de perto pelo estado matrimonial. Lembremos que título e ocupação especializada não eram para todos, mas do fenótipo ninguém escapa, porém nem assim a Polícia o anotou com frequência, tal como em registros de tropa no sertão baiano setecentista. ${ }^{40}$

Cor de pele, como parte do fenótipo, seria o caso se os números sobre qualidade de cor dissessem respeito exclusivamente a ela, o que não sucedeu, salvo em raras ocasiões. No quesito qualidade de cor se incluem crioulos forros e libertos, ${ }^{41}$ pardos forros e libertos, homens pardos, pretos forros e libertos, homens pretos, cabras e cabrinhas; mas

escravidão? (Rio de Janeiro no limiar do século XVIII)", in Denise Demetrio, Italo Santirocchi e Roberto Guedes (orgs.), Doze capitulos sobre cativar gente e governar escravos (Brasil e Angola, séculos XVII-XIX) (Rio de Janeiro: Mauad X, 2017), pp. 17-50.

40 Ivo, Homens de caminho, cap. 4.

41 Crioulo nada tem a ver com qualidade de cor, mas foi incluído para efeito de cálculo. 
também incluímos, para efeito de cálculo, morenos, mulatos, mulatinhos, e alguns poucos brancos e índios, todos termos de época. Havia até mestiços, também termo de época, mas não se encontra um único negro entre os chefes de tropa. Mesclava-se, portanto, qualidade (pardo, preto, branco) com condição jurídica (forro, escravo).

Figura 1 - Tipo e frequência (\%) de informações sociais e corporais dos chefes de tropas $(1809-1821)^{42}$

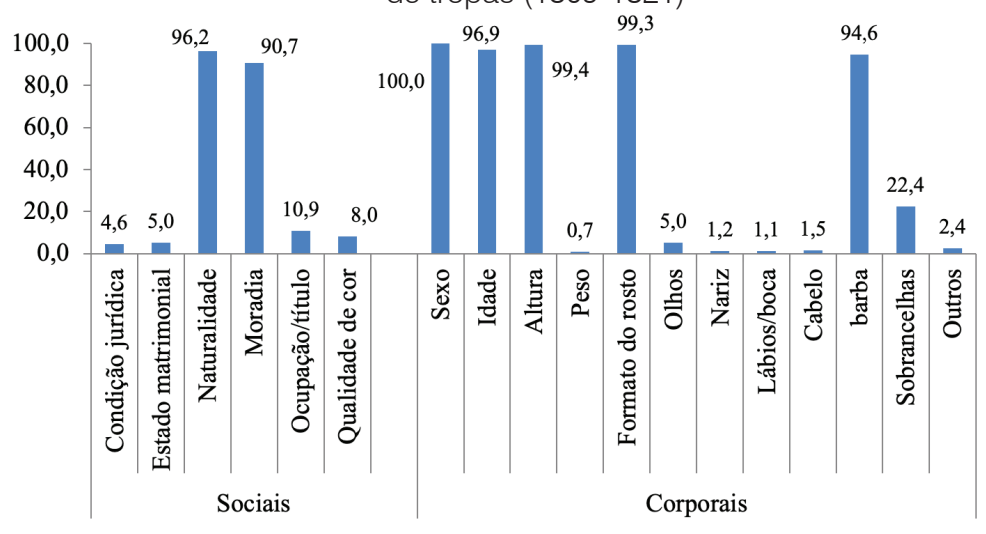

Figura 2 - Tipo e frequência (\%) de informações sociais e corporais dos chefes de tropas (1822-1833)

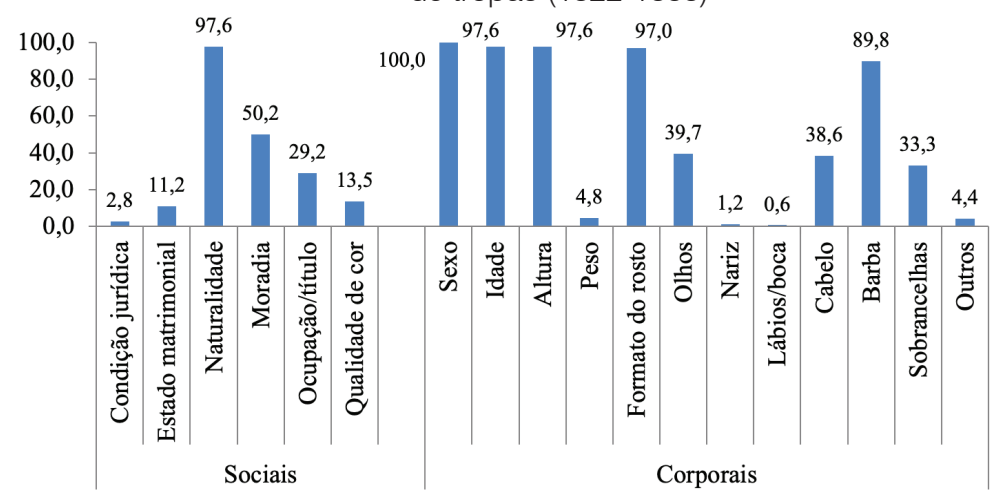

42 Para aferir os números absolutos referentes a despachos e passadores, ver: Fragoso e Guedes, "Alegrias e artimanhas"; Tráfico de escravos . 
Por seu turno, a condição jurídica, muito pouco mencionada, só abrange escravos e forros. Raramente se dizia que alguém era livre, aqui considerado como tal pela ausência do registro. Estamos cientes da debilidade dos dados e só para se ter uma ideia do sub-registro da qualidade de cor e da condição de forro na documentação consultada, ressaltamos a parca menção a libertos. Decerto, havia muito mais forros do que se pode imaginar e, sem dúvida alguma, a imensa maioria dos livres não era branca. ${ }^{43}$ Nesses aspectos, as informações da Polícia contrastam bastante com as palavras de viajantes que enfatizaram que a cidade era formada por uma multidão de pretos e mulatos, ${ }^{44}$ e também com um censo populacional de 1799, o qual assinala, pelo menos, um forro (pardo ou preto) para cada 2,1 brancos, que no documento significa livres. ${ }^{45}$

Em síntese, pelos dados disponíveis, se aquelas expressões de qualidade de cor da Polícia dissessem respeito ao fenótipo ou ao que anacronicamente alguns chamam de raça, o governo preferencialmente não racializava os transeuntes que circulavam pelo Sul-Sudeste. A qualidade de cor das pessoas não era importante para governar o fluxo populacional que ocorria pelas partes mais ricas da colônia portuguesa na América, e nem do nascente Império do Brasil.

Sobre os traços físicos, o sexo, aferido pelo nome, era informado para todos (Figuras 1 e 2). Afora isso, a Polícia reparou idade, altura e formato do rosto (comprido ou redondo), aspectos fundamentais para dar cara à população. Evidentemente, a idade não se resume à dimensão corporal, pois traz em si informações sociais diversas (maturidade, responsabilidade

43 Johann Moritz Rugendas notou que o fenótipo, por si só, não definia a cor social: "O número de mulatos é incomparavelmente maior, e seria difícil, principalmente [isto é, não apenas] na massa do povo, encontrar muitos indivíduos cujo aspecto autorize concluir com segurança que não herdaram sangue africano de seus antepassados. Por mais estranha que pareça a afirmação que vamos fazer, cabe menos à vista e à fisiologia do que à legislação e à administração resolver sobre a cor de tal ou qual indivíduo. Os que não são de um negro muito pronunciado e não revelam de maneira muito incontestável os caracteres da raça africana não são, necessariamente, homens de cor; podem, de acordo com as circunstâncias, ser considerados brancos". Johann Moritz Rugendas, Viagem pitoresca através do Brasil, São Paulo: Círculo do Livro, 1983, p. 216.

44 Lara, Fragmentos setecentistas, cap. 2.

45 Brasil, Resumo Total da População que existia no ano de 1779, compreendidas as quatro freguesias do Rio de Janeiro", <https://bit.ly/2Or5vJ3>, acessado em 8/10/2019. Para outros locais: Júlia Ribeiro Aguiar, "Por entre as frestas das normas: nobreza da terra, elite das senzalas e pardos forros em uma freguesia rural do Rio de Janeiro (São Gonçalo, sécs. XVII-XVIII)" (Dissertação de Mestrado, Universidade Federal do Rio de Janeiro, 2015). 
civil e criminal etc.), mas a incluímos nos quesitos físicos porque, querendo ou não, dependem dela a cor ou mesmo a presença do cabelo, a aura da cara, a alma manifesta no olhar, a cor da pele, a curvatura da coluna, o peso do corpo, a barba dos homens... Se inserirmos a qualidade de cor nos traços físicos, posto que se podia dizer, por exemplo, "Fulano de rosto comprido e trigueiro", ainda assim a administração da República não primava pela racialização. Quando informada, a cor do rosto nunca era branca, parda ou preta, sempre corada, descorada, vermelha, clara, morena ou trigueira. Dessa forma, corados, descorados, vermelhos, claros, morenos e trigueiros de rosto foram incluídos no quesito qualidade de cor, junto com homens pardos, pretos forros, entre outros, como os poucos índios que foram listados. Ainda assim, não é possível comparar a frequência de informação atinente à qualidade de cor com as de idade, altura e formato do rosto em cada fase. A cor era praticamente irrelevante. Entre 1822 e 1833, aliás, era muito mais pertinente à Polícia anotar a aparência dos olhos, dos cabelos e das sobrancelhas, isso para não dizer da barba.

Certamente, o não dito nos diz muito sobre uma sociedade, mas o que é dito nos assevera muito mais sobre ela. Pois bem: se a tal raça/ cor não era importante, quais as caras da escravidão e da liberdade? Para compreender, é preciso atentar para a barba. Entre os componentes do rosto, a barba salta aos olhos nos gráficos (Figuras 1 e 2), sendo, na imensa maioria das vezes, o aspecto mais realçado. A barba era uma marca do rosto que não podia deixar de ser informada, mesmo quando era ausente, já que geralmente se assinalava "Beltrano sem barba". Excluindo as mulheres do cômputo, informações sobre a barba constam para 24.047 $(95,3 \%)$ dos 25.214 homens cabeças de tropa entre 1809 e 1821, e para $7.236(93,5 \%)$ dos 7.739 do segundo período.

Havia diferenças substanciais, porém, sobre o tipo de barba, conforme a condição jurídica e a posição na tropa. Frequentemente, escravos despachados, não os cabeças de tropa, não eram dignos de serem classificados com barba aos olhos dos funcionários do governo. Deve-se lembrar que os cativos que lideravam tropas deviam ter autorização de seus senhores para viajar, embora não tenhamos encontrado evidências nesse sentido. Era, de qualquer modo, na condição de cabeça de tropa, com permissão ou não de seu senhor, que os escravos eram mais aludidos 
com determinados tipos de barba, diferentemente de seus pares despachados/vendidos, que majoravam pela ausência de pelo no rosto (Figura 9).

Para analisar a relação da honra com a barba em uma sociedade escravista, subdividimos as barbas em cinco tipos, de acordo com o volume: (1) "Bastante barba", inclui os que foram descritos com barba grande, cheia, grossa, comprida, cerrada, muita barba, com suíças, ou suíças grandes - totalizaram 21.441 homens, dos quais $21.422(99,9 \%)$ eram de "bastante barba"-; 2) "Pouca barba", abrange os designados como tais e os de muito pouca barba, de buço, de ponta de barba, de barba rala, parcial, fina ou delgada - somaram 7.886 homens, incluindo os 6.963 com pouca barba -; 3) "Barba regular", como no original; 4) "Sem barba", também conforme o original, mas adicionamos a eles os 1.670 casos sem informação, que juntos alcançam 3.391; 5) "Cor da barba", informada para 75 homens, sem qualquer outra alusão a volume. Como se nota, a imensa maioria dos chefes de tropa usava bastante barba na cara. Parece que, em termos de barba, tamanho era documento e dava cara ao viajante.

Para prosseguirmos com a abordagem - excluídos os de barba regular (178 casos), dois casos de "barba crespa" e "com bigodes", dado seu difícil enquadramento, e os aludidos apenas com a cor da barba, que serão analisados adiante - agregamos dois grandes grupos: (a) os de bastante barba e (b) os de pouca barba/sem alusão a ela. Comparamo-los para saber se livres e escravos aparentavam caras diferentes conforme o tipo de barba, mas antes cotejaremos os livres a partir do critério de naturalidade e faixa etária (até 12 anos de idade, de 13 a 20, de 21 a 35, de 36 a 45, e mais de 45 anos de idade) para aferir se a barba era uma marca indelével da face, capaz de conferir honra, ou se variava mais em função da naturalidade e idade.

\section{A barba na cara de portugueses, brasileiros ${ }^{46} \mathrm{e}$ africanos}

Os portugueses, proporcionalmente, eram os que mais portavam bastante barba (Figuras 3 e 4). Considerando apenas os brasileiros livres sem

46 O emprego de "brasileiro" e "português" significa apenas naturalidade, sem políticas de cidadania, mesmo no pós-Independência do Brasil. Assunto em Gladys Sabina Ribeiro, A liberdade em construção: identidade nacional e conflitos antilusitanos no Primeiro Reinado, Rio de Janeiro: Relume Dumará, 2002. Africanos são os originários da África. Nenhum dos designativos é da documentação. 
qualquer qualidade de cor, os índices diminuem um pouco, em ambos os períodos (Figura 5). No segundo momento, a diferença proporcional de portugueses com bastante barba em relação aos brasileiros se reduz, e quase se iguala aos brasileiros livres sem alusão a antepassado escravo (Figuras 3 e 4 ).

Figura 3 - Tipos de barba (\%) de chefes de tropas brasileiros e portugueses

(1809-1821)

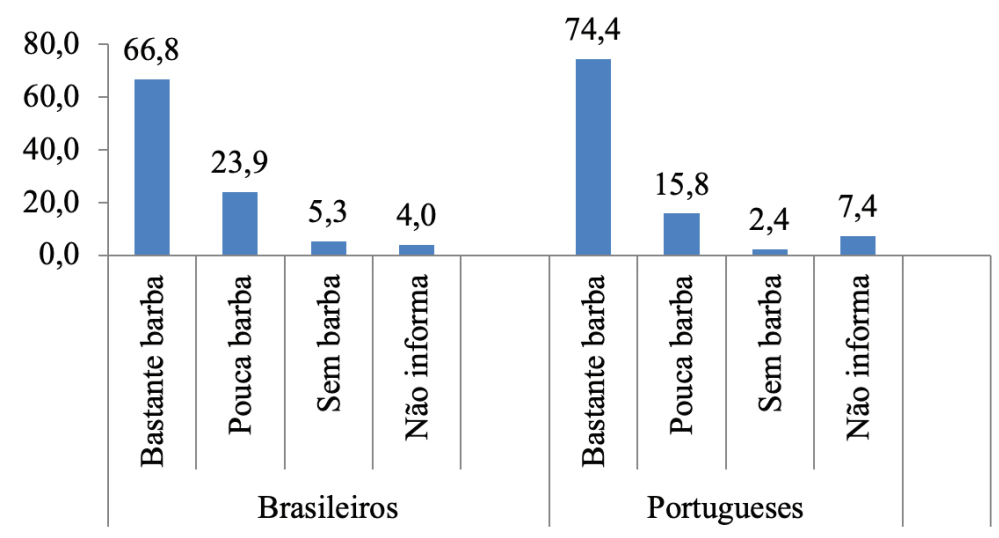

Figura 4 - Tipos de barba (\%) de chefes de tropas brasileiros e portugueses (1822-1833)

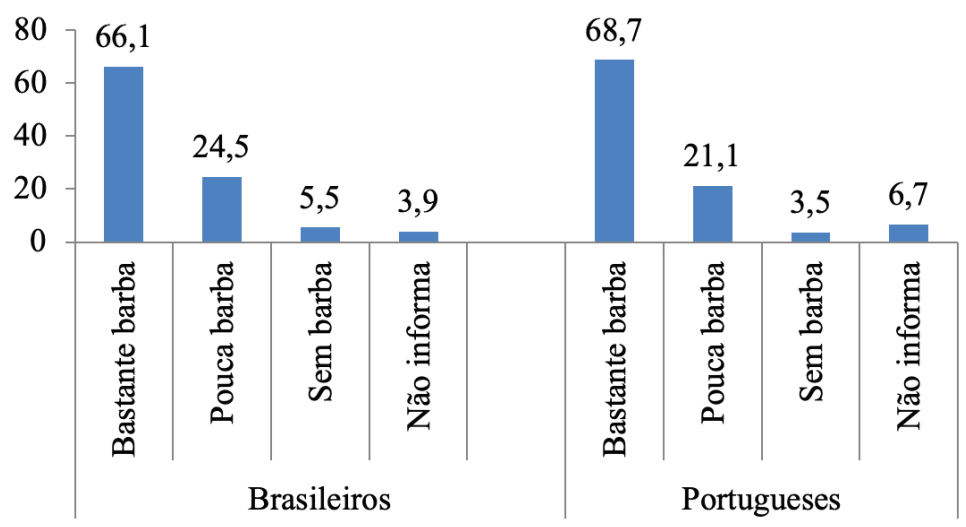


Figura 5 - Tipos de barba (\%) de chefes de tropas brasileiros livres sem qualidade de cor (1809-1833)

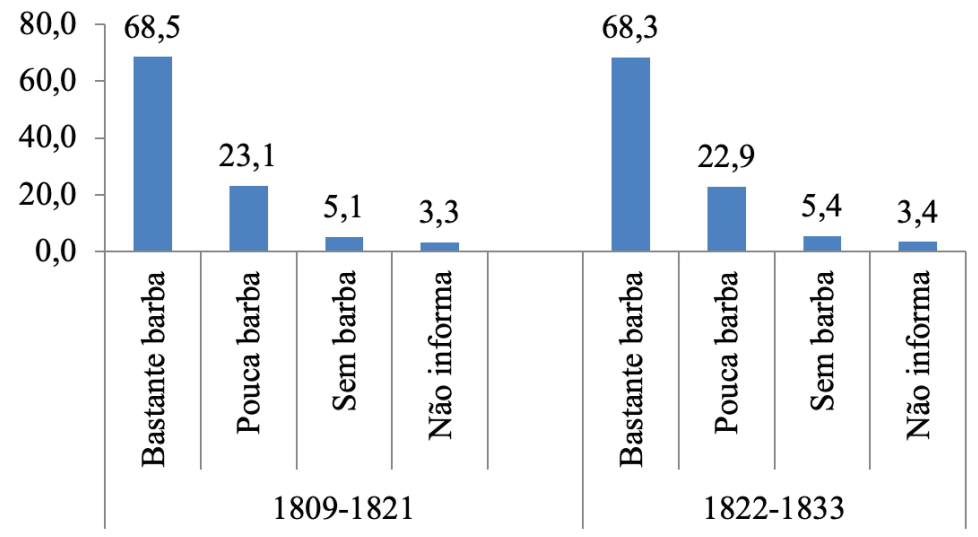

É óbvio que ser barbado, ou não, varia conforme o gosto particular, a moda, o evento social, as circunstâncias de poder ou não barbear-se etc. É certo também que o pelo facial protege o rosto contra insetos e intempéries climáticas, e até dos raios solares, o que muito convém aos que viajavam expostos ao tempo nas condições da época. Porém, lembremos que os viajantes partiam do Rio de Janeiro, o que sugere que em algum momento puderam raspar sua barba quando de sua estadia na cidade, se assim o quisessem. Logo, por si só, o motivo basilar de a grande maioria ter "bastante barba" não era o fato de serem, de saída, viajantes.

Brasileiros livres, principalmente sem cor, e portugueses apresentavam-se ou eram vistos no mais das vezes com "bastante barba", o que tem menos a ver com a naturalidade do que com serem, majoritariamente, livres ou tidos como tal. Prova disso pode ser observada ao se perscrutar os tipos de barba, associando-os à naturalidade e à condição jurídica (Figura 7). Constata-se, igualmente, que brasileiros livres com qualidade de cor possuíam menos "bastante barba" do que os livres sem essa qualidade, ambos nascidos no Brasil. Uma diferença de mais de 10\% em cada fase (Figuras 5 e 6 ). 
Figura 6 - Tipos de barba (\%) de chefes de tropa brasileiros livres com qualidade de cor*

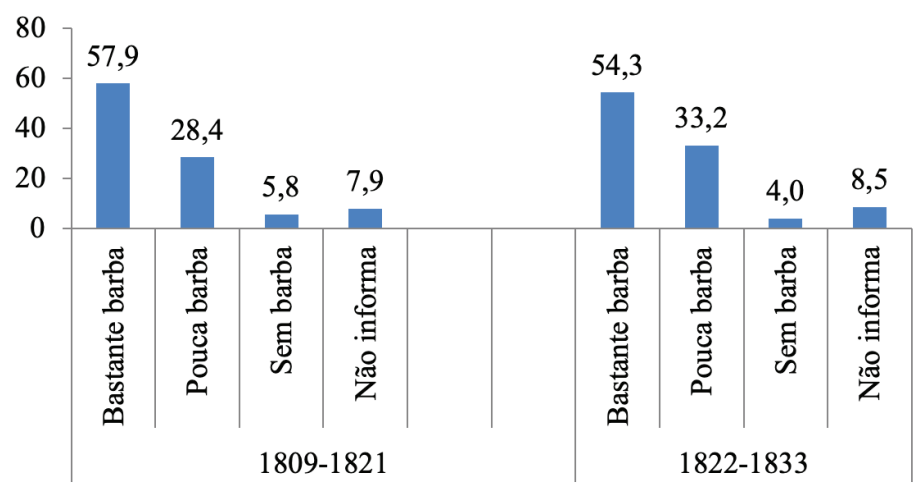

* Inclui crioulos, cabras, morenos, trigueiros, pardos e pretos, sem alusão à condição de forros.

Por seu turno, os escravos crioulos (nascidos no Brasil) usavam bem menos "bastante barba" do que os crioulos forros (Figura 7), e ambos estavam aquém das barbas grandes dos brasileiros livres, inclusive os com cor (Figuras 5, 6 e 7). Entre os nascidos no Brasil, o volume da barba era, respectivamente, maior conforme se ia da escravidão à liberdade, na seguinte ordem: escravos, forros (com ou sem qualidade de cor), egressos do cativeiro (pardo, preto, moreno, trigueiro, sem alusão à condição de forro) e livres. Infelizmente, apenas 18 cativos chefiavam tropas no segundo período, mas, mesmo assim, somente quatro deles eram de "bastante barba", ao passo que 13 dos 31 crioulos forros o eram. 
Figura 7 - Tipos de barba (\%) de chefes de tropas crioulos forros e escravos (1809-1821)

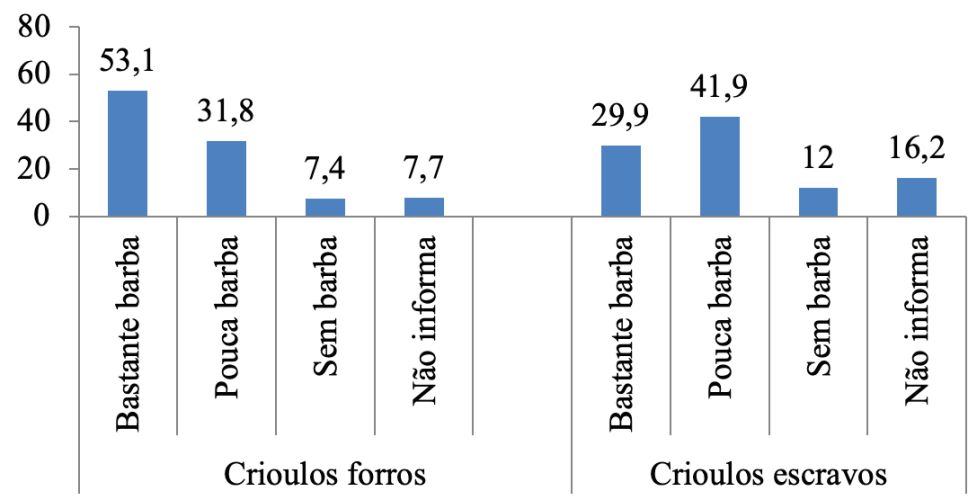

Ser escravo, portanto, marcava uma importante diferença no quesito cabelo na face. Com efeito, cativos crioulos (Figura 7) portavam menos "bastante barba" do que os africanos (Figura 8), mas com pouca diferença percentual. Por isso, africanos ou crioulos, os escravizados eram predominantemente de "pouca barba". Houve pouquíssima variação entre africanos, libertos ou escravos, daí não segmentarmos os forros porque, mesmo agregando os dois períodos, só 42 deles chefiaram tropas. Já os cativos africanos líderes de tropas e/ou que partiram sós totalizaram 251. De um modo geral, os africanos eram, em sua grande maioria, oriundos do que se chama África Central atlântica ou África Centro-Ocidental, área que contempla Angola, Benguela, Cabinda, Congo, Cassange, Rebolo e algumas outras procedências. Da África Ocidental, havia dezesseis, todos de Mina, e apenas oito da África Oriental, os moçambiques. ${ }^{47}$

47 A respeito de procedências africanas, Karasch, Slave Life; Miller, Way of death; Florentino, Em costas negras; Ferreira, "Dos Sertões"; Candido, An African Slaving; Mariza Soares, Devotos da cor: identidade étnica, religiosidade e escravidão no Rio de Janeiro, século XVIII, Rio de Janeiro: Civilização Brasileira, 2000. Ver ainda, sobre as ressignificações locais das identidades, Luís Nicolau Parés, A formação do candomblé: história e ritual da nação jeje na Bahia, Campinas: Editora Unicamp, 2007. Em trabalhos futuros, abordaremos a variação por grupo de procedência africana, comparativamente a crioulos, e conforme a naturalidade e moradia dos brasileiros livres e forros. As expressões de procedência no texto estão conforme o original. Por exemplo: João Angola. Congo não necessariamente alude a origem no Reino do Congo. 
Figura 8 - Tipos de barba (\%) de chefes de tropas africanos (forros e escravos), e africanos escravos (1809-1821)

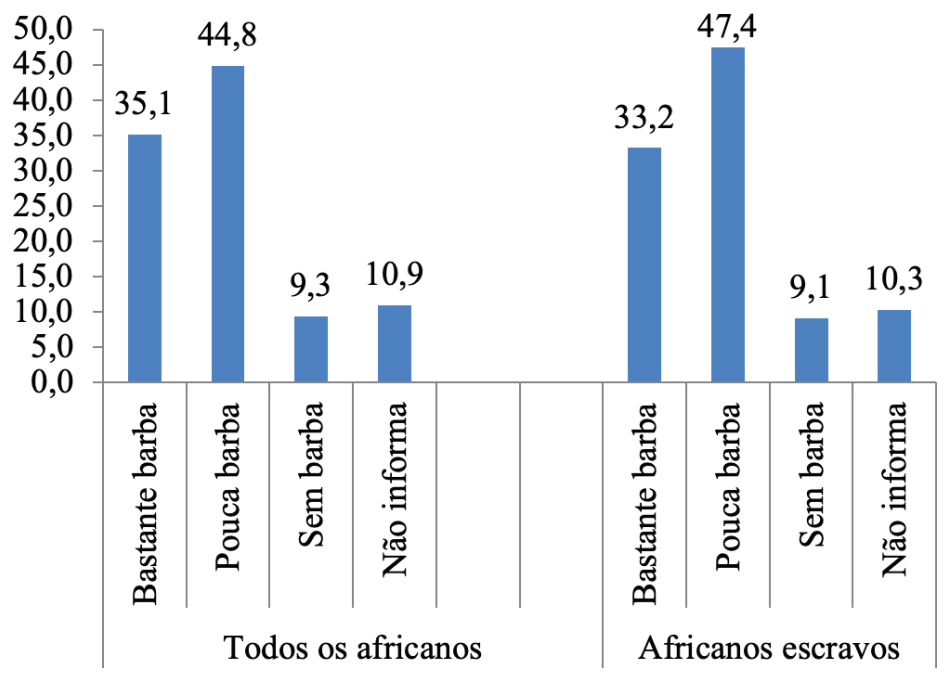

Pelos dados coligidos, pode-se dizer, portanto, que, como tendência predominante, viajantes livres tinham mais "bastante barba" do que forros e mais ainda do que escravos, ou assim eram vistos pelos escrivães da Polícia da Corte; ou ainda, o que dá no mesmo, que escravos eram de "pouca barba", "sem barba", ou aludidos sem menção a ela, em sua grande maioria. O contraste com os livres, e mesmo com os crioulos forros, é evidente, "tá na cara". Entre livres sem cor e escravos situavam-se egressos do cativeiro sem alusão à sua condição de manumitidos.

Lembrando que lidamos com os chefes de tropa, ou com aqueles que partiam sozinhos, seria a idade, e não tanto a naturalidade e a condição jurídica, o que mais fazia diferença? Observemos os classificados com "barba branca", "pinta de branco" ou "barba pintada de branco". Ainda que não saibamos se se trata, nos dois últimos casos, de pontos brancos na barba, o que é mais provável, e/ou de uma barba pintada de branco, visto que nenhuma outra fonte que analisamos se refira a isto en- 
fática e textualmente, ${ }^{48} \mathrm{o}$ fato é que, entre 1809 e 1821 , dos 529 homens com branco na barba, à revelia do volume, e com idade mencionada, 496 $(93,8 \%)$ tinham 40 anos ou mais, dentre os quais 258 (48,8\%) estavam acima de 50 anos de idade. No período de 1822 a 1833, dos 28 nas mesmas condições, 25 tinham mais de 39 anos, 15 deles acima de 50. Para os padrões da época, significa dizer que ter algo de branco na barba ou a barba branca, ainda que pintada, era quase exclusivamente para idosos, ou então, para homens bem maduros. Era uma questão etária.

Inversamente, para 1809-1821, nenhum dos 78 tropeiros com menos de 14 anos de idade tinha "bastante barba" ou "branca". Em geral, foram descritos com "pouca barba", "sem barba" ou sem menção a ela, bem como os 17 quase imberbes do período de 1822 a 1833. A média de idade dos viajantes era de 32,2 anos, em ambos os períodos, o que não é baixo para os padrões da época. Ao todo, houve 16.755 (64\%) classificações de homens com "bastante barba". Decerto, ter muita ou pouca barba depende, entre outros aspectos, das características de cada homem, de questões hormonais e genéticas, mas no que concerne à idade pode-se dizer que os mais velhos tendiam a ter "bastante barba" com muito mais frequência, a exemplo dos brasileiros (Tabela 1); em proporção, quanto mais velho, mais "bastante barba". No extremo oposto, os de até 20 anos de idade não tinham pelo na cara, usavam "pouca barba", ou nem se informava. Índices que, agregados, alcançaram $87,3 \%$ na segunda fase.

48 Centenas de inventários post-mortem e os viajantes Ernst Ebel, O Rio de Janeiro e seus arredores em 1824, São Paulo: Companhia Editora Nacional, 1972; Thomas Ewbank, A vida no Brasil ou diário de uma visita ao país do cacau e das palmeiras, Rio de Janeiro: Conquista, 1973, 2 v.; Maria Grahan, Diário de uma viagem ao Brasil, São Paulo: Companhia Editora Nacional, 1956; Theodor von Leithold e Ludwig von Rango, O Rio de Janeiro visto por dois prussianos em 1819, São Paulo: Companhia Editora Nacional, 1966; Thomas Lindley, Narrativa de uma viagem, São Paulo: Companhia Editora Nacional, 1969; Luccock, Notas sobre o Rio de Janeiro; Carl Friedrich P. von Martius e Johann Baptist von Spix, Viagem pelo Brasil, São Paulo: Melhoramentos, 1961; RUGENDAS, Viagem pitoresca; Jean-Baptiste Debret, Viagem pitoresca e histórica ao Brasil, São Paulo: Edusp, 1989, v. 3. Esta edição não contém texto, mas abrange 139 aquarelas não reproduzidas na edição de Firmin Didot, em 1834. Não tivemos acesso à edição de R. de Castro Maya, publicada em Paris em 1954. 
Tabela 1 - Tipos de barba por faixas etárias (em anos) dos brasileiros

\begin{tabular}{|c|c|c|c|c|c|c|c|c|c|}
\hline \multicolumn{10}{|c|}{1809 a 1821} \\
\hline $\begin{array}{c}\text { Tipos de } \\
\text { barba }\end{array}$ & \multicolumn{2}{|c|}{$\begin{array}{c}\text { Bastante } \\
\text { barba }\end{array}$} & \multicolumn{2}{|c|}{$\begin{array}{l}\text { Pouca } \\
\text { barba }\end{array}$} & \multicolumn{2}{|c|}{ Sem barba } & \multicolumn{2}{|c|}{ Não informa } & Total \\
\hline $\begin{array}{l}\text { Faixa } \\
\text { etária }\end{array}$ & $\mathrm{N}^{\circ}$ & $\%$ & $\mathrm{~N}^{\circ}$ & $\%$ & $\mathrm{~N}^{\circ}$ & $\%$ & $N^{\circ}$ & $\%$ & $N^{\circ}$ \\
\hline Até 20 & 468 & 17,7 & 955 & 36,1 & 850 & 32,1 & 373 & 14,1 & 2.646 \\
\hline 21 a 35 & 8.024 & 67,4 & 3.335 & 28,0 & 256 & 2,2 & 289 & 2,4 & 11.904 \\
\hline $\begin{array}{c}\text { Mais de } \\
35\end{array}$ & 5.877 & 85,5 & 808 & 11,8 & 15 & 0,2 & 172 & 2,5 & 6.872 \\
\hline \multicolumn{10}{|c|}{1822 a 1833} \\
\hline $\begin{array}{c}\text { Tipos de } \\
\text { barba }\end{array}$ & \multicolumn{2}{|c|}{$\begin{array}{c}\text { Bastante } \\
\text { barba }\end{array}$} & \multicolumn{2}{|c|}{$\begin{array}{l}\text { Pouca } \\
\text { barba }\end{array}$} & \multicolumn{2}{|c|}{ Sem barba } & \multicolumn{2}{|c|}{ Não informa } & Total \\
\hline $\begin{array}{l}\text { Faixa } \\
\text { etária }\end{array}$ & $\mathrm{N}^{\circ}$ & $\%$ & $\mathrm{~N}^{\circ}$ & $\%$ & $\mathrm{~N}^{\circ}$ & $\%$ & $\mathrm{~N}^{\circ}$ & $\%$ & $\mathrm{~N}^{\circ}$ \\
\hline Até 20 & 101 & 12,7 & 242 & 30,4 & 246 & 30,9 & 206 & 25,9 & 795 \\
\hline 21 a 35 & 1.442 & 57,6 & 818 & 32,7 & 60 & 2,4 & 184 & 7,3 & 2.504 \\
\hline $\begin{array}{c}\text { Mais de } \\
35\end{array}$ & 1.129 & 77,0 & 201 & 13,7 & 4 & 0,3 & 132 & 9,0 & 1.466 \\
\hline
\end{tabular}

Fonte: ANRJ-CP, Códices 390, 411, 424 e 425.

Pelo dito, a coorte etária ajuda a entender por que os homens se identificavam com "bastante barba", mas é sempre bom lembrar que ter "bastante barba" era uma opção, a idade não explica tudo. O "bastante barba" era para homens feitos, física e socialmente, mas mantê-la era uma escolha, ainda que nem todos os homens pudessem exibi-la, a depender de características físicas relacionadas à condição jurídico-social, à origem, ao fenótipo. Seria esse o caso dos escravos despachados?

\section{A cara dos escravos despachados ${ }^{49}$}

Apesar das variações espaço-temporais, a população escrava no Brasil, especialmente na cidade do Rio de Janeiro, era predominantemente adulta (acima de 14 anos) e do sexo masculino, ainda que as cativas estivessem

49 Para o cômputo dos cativos nos valemos de ANRJ-CP, códices 390, 411, 424 e 425. 
em maior número na área urbana que no meio rural. ${ }^{50}$ Os escravos despachados não fogem à regra, embora a presença de mulheres não fosse desprezível no segundo período (Tabela 2). Mas, como são desprovidas de barba, voltemos à faixa etária deles e sua relação com os pelos da cara (Tabela 3). Antes, no entanto, o gráfico da Figura 9 realça a pouquíssima participação de escravos com bastante barba.

Tabela 2 - Sexo dos escravos despachados

\begin{tabular}{ccccc}
\hline & \multicolumn{4}{c}{ Períodos } \\
\hline \multirow{2}{*}{ Sexo } & No & $\%$ & No 1822 a 1833 & $\%$ \\
Masculino & 2.648 & 86,5 & 4.339 & 75,3 \\
Feminino & 415 & 13,5 & 1.426 & 24,7 \\
Total & 3.063 & 100,0 & 5.765 & 100,0 \\
\hline
\end{tabular}

Fonte: ANRJ-CP, Códices 390, 411, 424 e 425.

Figura 9 - Tipos de barba (\%) dos escravos despachados

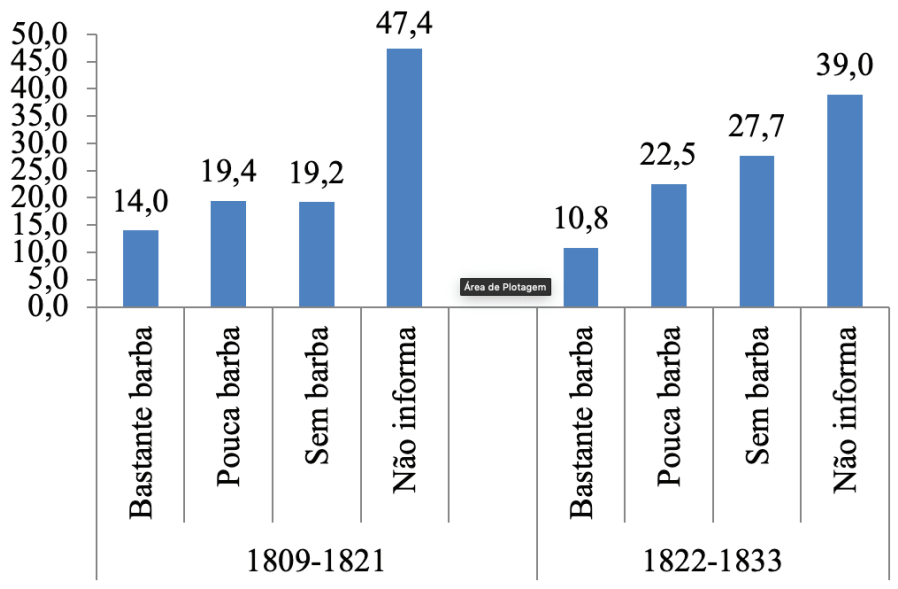

50 Jacob Gorender, O escravismo colonial, $5^{\mathrm{a}}$ ed., São Paulo: Ática, 1988; Douglas Libby, "Demografia e escravidão", Revista de História, v. 3, n. 1 (1992), pp. 267-294; Clotilde Andrade Paiva e Douglas Libby, "Caminhos alternativos: escravidão e reprodução em Minas Gerais do século XIX", Estudos Econômicos, v. 25, n. 2 (1995), pp. 203-233; Manolo Florentino e José Góes, A paz das senzalas: familias escravas e tráfico atlântico. Rio de Janeiro, 1790-1850, Rio de Janeiro: Civilização Brasileira, 1997; José Flávio Motta, Corpos escravos, vontades livres: posse de escravos e familia escrava em Bananal, São Paulo: Fapesp: Annablume, 1999; Guedes, Na pia batismal. 
Tabela 3 - Tipos de barba por faixas etárias (em anos) dos escravos despachados

\begin{tabular}{|c|c|c|c|c|c|c|c|c|c|}
\hline \multicolumn{10}{|c|}{1809 a 1821} \\
\hline Tipos de barba & \multicolumn{2}{|c|}{$\begin{array}{c}\text { Bastante } \\
\text { barba }\end{array}$} & \multicolumn{2}{|c|}{$\begin{array}{l}\text { Pouca } \\
\text { barba }\end{array}$} & \multicolumn{2}{|c|}{$\begin{array}{l}\text { Sem } \\
\text { barba }\end{array}$} & \multicolumn{2}{|c|}{ Não informa } & Total \\
\hline Faixa etária & $\mathrm{N}^{\circ}$ & $\%$ & $\mathrm{~N}^{\circ}$ & $\%$ & $N^{\circ}$ & $\%$ & $N^{\circ}$ & $\%$ & \\
\hline Até 14 & 1 & 0,1 & 2 & 0,2 & 9 & 1,0 & 251 & 98,7 & 914 \\
\hline 15 a 20 & 8 & 0,9 & 68 & 8,0 & 226 & 26,5 & 421 & 64,6 & 854 \\
\hline 21 a 35 & 145 & 22,3 & 228 & 35,0 & 52 & 8,0 & 226 & 34,7 & 651 \\
\hline Mais de 35 & 65 & 49,6 & 30 & 22,9 & 2 & 1,5 & 34 & 26,0 & 131 \\
\hline \multicolumn{10}{|c|}{1822 a 1833} \\
\hline Tipos de barba & \multicolumn{2}{|c|}{$\begin{array}{c}\text { Bastante } \\
\text { barba }\end{array}$} & \multicolumn{2}{|c|}{$\begin{array}{l}\text { Pouca } \\
\text { barba }\end{array}$} & \multicolumn{2}{|c|}{$\begin{array}{c}\text { Sem } \\
\text { barba }\end{array}$} & \multicolumn{2}{|c|}{ Não informa } & Total \\
\hline Faixa etária & No & $\%$ & No & $\%$ & No & $\%$ & No & $\%$ & \\
\hline Até 14 & 2 & 0,8 & 1 & 0,4 & 5 & 2,1 & 228 & 96,6 & 236 \\
\hline 15 a 20 & 5 & 1,1 & 32 & 7,2 & 104 & 23,5 & 302 & 68,2 & 443 \\
\hline 21 a 35 & 57 & 14,4 & 136 & 34,4 & 36 & 9,1 & 166 & 42,0 & 395 \\
\hline Mais de 35 & 42 & 42,9 & 23 & 23,5 & 1 & 1,0 & 32 & 32,7 & 98 \\
\hline
\end{tabular}

Nota-se a mesma tendência de os mais velhos usarem mais "bastante barba", conforme aumenta a faixa etária, mas os índices são incomparáveis aos dos livres e forros. Mesmo entre os com mais de 35 anos de idade, não chega a 50\% os que tinham "bastante barba". Apesar disso, escravos com mais idade traziam alguma diferença na cara. Tais escravos podiam ser daqueles com mais recursos no cativeiro, como pesquisas já sublinharam há algum tempo. ${ }^{51}$ Porém, nem mesmo entre os homens feitos, de 21 a 35 anos, majoravam os com mais barba, que nunca chegaram a um quarto deles. Em síntese, não era, necessariamente, a faixa etária dos escravos o que os tornava menos barbados. O que seria, então?

Para além de uma ideia prévia dos escrivães do governo, segundo a qual os cativos não usariam barba grande, uma série de circunstâncias que interferem na estética (o parecer ser) pode explicar

51 Florentino e Góes, A paz das senzalas; Slenes, Na senzala uma flor. 
a ausência ou escassez de pelos, situações que vão de propensões físicas a fatores culturais, sociais e políticos, ou relacionados à origem genética. Sem adentrar pormenorizadamente nos meandros das representações pictóricas em obras de viajantes, ${ }^{52}$ não deixa de ser interessante, todavia, que algumas pranchas de Jean Baptiste Debret, que esteve na corte joanina do Rio de Janeiro, não evidenciem cativos com barba, ${ }^{53}$ nem mesmo a famosa prancha de autoria de Rugendas, Negros no porão do navio, representa cativos barbudos, ainda que tivessem cabelos na cabeça. As barbas estavam aparentemente bem raspadas para quem vinha de uma jornada extenuante, o que talvez se deva à quarentena. ${ }^{54}$ Mas, também não há nenhum homem que se possa considerar com bastante barba nas gravuras Habitação de Negros, Preparação da raiz de mandioca e Castigo público na Praça de Santana ${ }^{55}$ ao passo que, quando há homens livres com ascendência europeia - em Costumes do Rio de Janeiro e Costumes de São Paulo e Habitantes de Minas -, eles são estilizados com grandes costeletas e/ou barbas e bigodes. Tampouco havia barbados nos desenhos Jogo da Capoeira, Batuque e Negro e Negra em uma Fazenda ${ }^{56}$ Ainda em Rugendas, em seus desenhos exclusivos de rostos de escravos não predominam barbudos. Por exemplo, não usam grandes barbas os homens pintados nas pranchas (1) Negro Cabinda, Quiloa, Rebolo, Mina, (2) Negros Moçambiques, (3) Negro Benguela, Angola, Congo, Monjolo e (4) Negros crioulos (ver estas imagens no Anexo). O homem Ango-

52 Vide Robert Slenes, "As provações de um Abraão Africano: a nascente nação brasileira na viagem alegórica de Johann Moritz Rugendas", Revista de História da Arte e Arqueologia, n. 2 (1995-1996), pp. 271-309; Rafael de Bivar Marquese, "Exílio escravista: Hercule Florence e as fronteiras do açúcar e do café no Oeste paulista (1830-1879)", Anais do Museu Paulista: História e Cultura Material, v. 24, n. 2 (2016), pp. 11-51.

$53 \mathrm{Na}$ impossibilidade de reproduzir todas as imagens mencionadas no texto, mantivemos as principais, de rostos, no anexo.

54 Rugendas, Viagem pitoresca, p. 211. O mesmo se observa em Desembarque e Mercado de Escravo (pp. 212-214).

55 Rugendas, Viagem pitoresca, pp. 213, 217, 225.

56 Rugendas, Viagem pitoresca, p. 215. Em Preparação da raiz de mandioca, Castigo público na Praça de Santana, Costumes do Rio de Janeiro e Costumes de São Paulo e Habitantes de Minas, homens com grandes costeletas e/ou barbas e bigodes têm ascendência europeia (pp. $217,225,106,107,108)$. 
la de Rugendas parece ter aparado os pelos faciais, deixando "pouca barba", igualmente a um negro crioulo.

Por sua vez, Jean Debret também aquarelou aspectos interessantes na relação entre barba e sociedade escravista. Suas pranchas contêm pouquíssimos escravos com barba, vis-à-vis a homens europeus ou com ascendência europeia. A prancha Cabeças de negros de diferentes nações não os representa com muita barba (ver imagem no Anexo). Por outro lado, quando homens livres usam o bacalhau e a palmatória, o semblante senhorial do castigo é exibido de barba ou costeleta; e eventualmente era até o caso quando o algoz era escravo. ${ }^{57}$ Continuando com as faces da escravidão, no asseio do rosto, uma prancha de Debret, a propósito, elucida que cativos faziam barba (Anexo 6), não obstante as atividades dos barbeiros fossem muito além do barbear. As curas por eles praticadas são bem conhecidas, ${ }^{58}$ mas não se pode esquecer que também faziam barba e cabelo. Sobre esta imagem, o artista francês asseverou que os barbeiros ambulantes vagueavam "desde manhã pelas praias, nos portos, nas ruas e praças públicas, ou em torno das grandes oficinas", onde estavam certos de "encontrar clientes entre os negros de ganho (carregadores, negros de recados, os pedreiros, os carpinteiros, os marinheiros e as quitandeiras)". 59

Enfim, investido de sua autoridade, o capitão do mato de $\mathrm{Ru}-$ gendas usava bigode e costeleta um pouco mais salientes, ao contrário do cativo fugitivo que capturara ${ }^{60}$ Nas gravuras, portanto, assim como nos passaportes, trata-se de representar o (potencial) poder senhorial de homens livres, e mesmo de forros, muitos dos quais foram senhores de cativos, com barba, e a condição infame de subalternidade escrava sem barba.

57 Debret, Viagem pitoresca, v. 2, pp.110, 171, 175

58 Márcio de Souza Soares, "A doença e a cura: saberes médicos e cultura popular na corte imperial" (Dissertação de Mestrado, Universidade Federal Fluminense, 1999); André Luís Lima Nogueira, Entre cirurgiões, tambores e ervas: calunduzeiros e curadores ilegais em ação nas Minas Gerais (século XVIII), Rio de Janeiro: Garamond, 2016.

59 Debret, Viagem pitoresca, t. 2, pp. 66, 71-72.

60 Rugendas, Viagem pitoresca, p. 101. 


\section{Considerações finais}

O que mais a barba pode nos dizer sobre escravidão e liberdade? Se a escravidão desonrava ${ }^{61}$ e se distintas sociedades, mesmo em África, associavam escravos a características corporais inferiores, ${ }^{62}$ a condição jurídico-social destes na cidade do Rio de Janeiro se estampava no semblante, quer nos despachos e passaportes da Polícia, isto é, aos olhos dos agentes do governo, quer nas aquarelas de viajantes.

Morais e Silva, um quase compilador de Bluteau, foi sucinto na definição de barba: "s.t. A parte inferior do rosto, ocupada nos homens em geral pelo pêlo, ou cabelo do mesmo nome". Mais detalhista e etimologista - ainda que quase um século antes -, Bluteau fornece no verbete "barba" adágios que a associam à honra. Confirma-nos que a idade interfere na reputação de ter pelos no semblante, pois um dos significados figurativos de barba é: "Barbas. Idade, Anos. Estas barbas não fazem isto, ou um homem com estas barbas não faz isto", mas vimos que, sobretudo se estes homens fossem livres, maduros de respeito e com bastante barba, deviam se comportar como tais, como senhores em potencial. Outro aforismo era: "De barba a barba, honra se cata [...]. Queixadas, sem barbas, não merecem ser honradas. Mais honra há, que a barba. Bem sabe o gato, cujas barbas lambe. [...] Barba com dinheiro, honra ao cavaleiro". Escravos sem barbas não poderiam ter a mesma honra que homens livres. Nas gravuras de Debret, a barba impunha respeito, autoridade senhorial, mesmo nos escravos que, tendencialmente com mais barbas, fossem chefes de tropas investidos de autoridade por seus senhores. Aliás, militares frequentemente usavam barbas e bigodes, ${ }^{63}$ expressando poder. Aquelas associações não se faziam apenas no Blu-

61 Orlando Patterson, Slavery and Social Death, Cambridge, MA: Harvard University Press, 1982.

62 Harris Memel-Fotê, “L'esclavage dans les sociétés lignagères de l'Afrique noire: exemple de la Côte d'Ivoire précoloniale, 1700-1920" (Tese de Doutorado, École des Hautes Etudes en Sciences Sociales, 1988); “Culture et nature dans les représentations africaines de l'esclavage et de la traite négrière: cas des sociétés lignagéres", Isabel Castro Henriques e Louis Sala-Molins (orgs.), Déraison, esclavage et droite: les fondements idéologiques e juridiques de la traite négrière et de l'esclavage, Paris: Éditions Unesco, 2002, pp. 195-202. Ver também: Sean Stilwell, Slavery and slaving in African History. Cambridge: Cambridge University Press, 2014.

63 Debret, Viagem pitoresca, 1989, v. 3, pp. 191, 229. 
teau de 1720. No Novo dicionário, discorre-se longamente sobre pelos do semblante, que podiam encarnar a própria pessoa:

Barba larga, longa, como traziam os antigos e trazem ainda os Turcos etc.; cara, rosto, parte dianteira, proa de navio. Ir com a barba sobre outrem, ou sobre navio, ir seguindo de mui perto. Naus com a barba em terra, com a proa. Fazer as barbas, ou a barba, raspar o cabelo da barba com a navalha de barbear. Barba a barba com alguém, cara a cara - com a má ventura, arrostando-a, expondo-a. Pelejando barba a barba com o inimigo. Ter a barba tesa a alguém, ou - em teso, resistir-lhe com ânimo. Fazer tremer a barba, inspirar terror, temor, susto, assustar, atemorizar. Fazer barba medrosa, mostrar medo [...]. Comer, viver d'custa da barba longa, à custa, à sombra da autoridade (antigamente denotada pela barba longa de magistrados, militares, clérigos, frades, fidalgos, cavalheiros), viver à custa de pessoas autorizadas, ricas, poderosas. ${ }^{64}$

Ter barbas para fazer alguma cousa, ou para empreender, resistir, ter coragem, resolução, ou capacidade, talento. Fazerem-se as barbas hum ao outro, ajudarem-se mutuamente [...]. Lançar o gato às barbas de alguém, causar trabalho, tirar de si o mal e lançá-lo sobre outrem [...]. Homem de barbas, barbado, de aspecto venerável. ${ }^{65}$

Para Constâncio a barba personificava os homens, era atributo dos de aspecto venerável. Também Bluteau se reporta aos que diziam que

El- Rey Dom Fernando foi o primeiro que fez a barba em Portugal, que o costume de cabelos e barbas grandes usarão por muitos anos os Portugueses no tempo del-Rey D. João primeiro, e muitos anos depois andaram com o cabelo cortado, e com grande barba [...] tão aceitas, e tão bem vistas, que na estimação do vulgo chegaram a ser distintivo dos homens honrados.

64 Francisco Solano Constâncio, Dicionário crítico e etimológico da língua portuguesa, Paris: Officina Typographica de Casemir, 1836, p.160.

65 Constâncio, Dicionário crítico, p. 160. 
No tempo do regente, Dom João VI, e do imperador do Brasil, Dom Pedro I, ambos com costeletas e/ou barbas e bigodes, ${ }^{66}$ a liberdade (potência de condição senhorial) exibia pelos que honravam a face, preferencialmente "bastante barba". Também a escravidão evidenciava outras marcas, como "sinais" (escarificações) da terra nas faces, "sinais de sua nação", ou similares, em 338 cativos despachados. A escravidão desonrava a cara, deixando os escravos sem barba, com pouca barba, ou sem menção a ela, "com a cara no chão". Até o não dito do semblante dos escravos revelou sua mácula, comparativamente aos livres portugueses, brasileiros sem cor, com cor, aos forros, aos homens maduros de cãs e barbas brancas. Mas os barbeiros também tiravam pelos do rosto dos cativos. Mesmo que certos escravos não tivessem propensão biológica à barba, apará-la ou raspá-la, em uma sociedade escravista na qual o ser e o parecer ser eram indissociáveis, referendava nas suas próprias faces a deferência a homens barbados. ${ }^{67}$

Todavia, por outro lado, em quimbundo, kimuézu é adjetivo que significa "Barbado. Barbudo. De barbas compridas. Sub[stantivo] Barbas crescidas e mal cuidadas. Barbaçana". Aí a imagem de Debret sobre escravos raspando a barba ganha outros contornos. Significa o recobrar a honra. O que para uns era infâmia, para outros denotaria honra. De um lado, tratava-se da deferência ao poder dos (proto)senhores barbudos mostrando a cara da liberdade; de outro, era o raspar a barba para viver com honra na escravidão. Parafraseando o dicionarista, "barbas aparadas e bem cuidadas". A cara da escravidão.

Recebido em 13/3/2018 e aprovado em 13/3/2019

66 Debret, Viagem pitoresca, 1989, v. 3, p. 152.

67 Um uma sociedade escravista supõe, além da presença da mão de obra escrava, "distinções jurídicas entre escravos e livres", "princípios hierárquicos baseados na escravidão", "atitudes senhoriais dos proprietários" e "deferência dos socialmente inferiores". Schwartz, Segredos internos, p. 209. 


\title{
Resumo
}

Referente ao Sul-Sudeste escravista do Brasil nas três primeiras décadas do século XIX, o artigo aborda assunto pouco conhecido pela historiografia: literalmente, a cara da escravidão e a cara da liberdade. A construção da face nesta sociedade escravista estava relacionada à infâmia da escravidão e à honra da liberdade, o que levou a diferentes percepções/classificações dos rostos por agentes da Polícia da Corte do Brasil. Protagonistas de suas aparências, homens livres, forros e escravos, de diferentes naturalidades, tiveram seus "retratos falados" descritos conforme suas condições jurídicas, origens e faixas etárias. Eram homens em trânsito que saíam do Rio de Janeiro para vários destinos. A barba era um atributo crucial para atestar honra-liberdade, e sua ausência ou pouco volume caracterizavam faces escravas. Para aferir a hipótese, utilizamos despachos de escravos e passaportes de viajantes emitidos pela Polícia da Corte entre os anos de 1809 a 1833, cruzados a gravuras de viajantes e dicionários de época.

Palavras-chave: cara - escravidão - liberdade - século XIX.

\begin{abstract}
Referring to the South-Southeast Brazilian slave society in the first three decades of the nineteenth century, the article addresses a little known subject by the historiography: literally, the face of slavery and the face of freedom. The construction of faces (physiognomy) in that slavery society was related to infamy of slavery and the honor of freedom, which took to different perceptions/classifications of faces by agents of Brazil's Court Police. Protagonists of their appearances, enslaved, manumitted and free men and women of different national and ethnic origins, had their "facial composites" described according to their legal condition, origin and age. They were men in transit through Rio de Janeiro to several destinations. The beard was a crucial attribute to authenticate honor-freedom, and its absence or thin volume characterized slave faces. To verify the hypothesis, we used dispatches of slaves and passports of issued by the Court Police between the years of 1809 to 1833, comparing them with engravings in travel logs and dictionaries.
\end{abstract}

Keywords: face - slavery - freedom - nineteenth century. 


\section{Anexos}

(1) Negro Cabinda, Quiloa, Rebolo, Mina

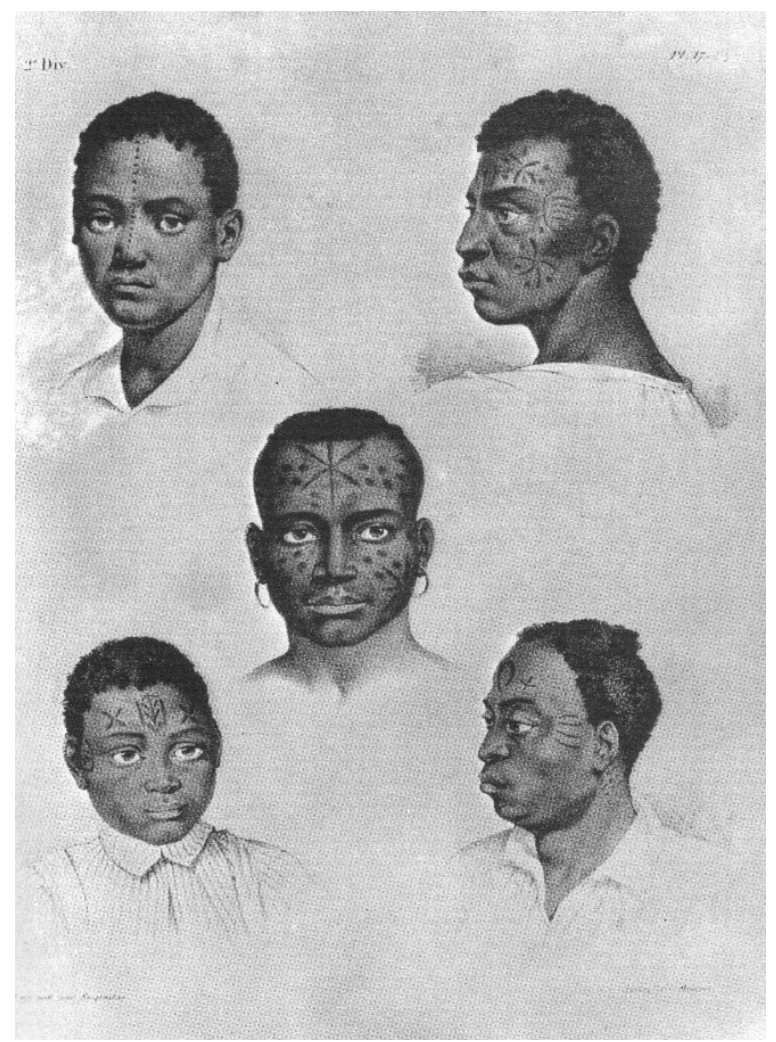

Fonte: Rugendas, Viagem pitoresca, s/d. 
(2) Negros Moçambiques

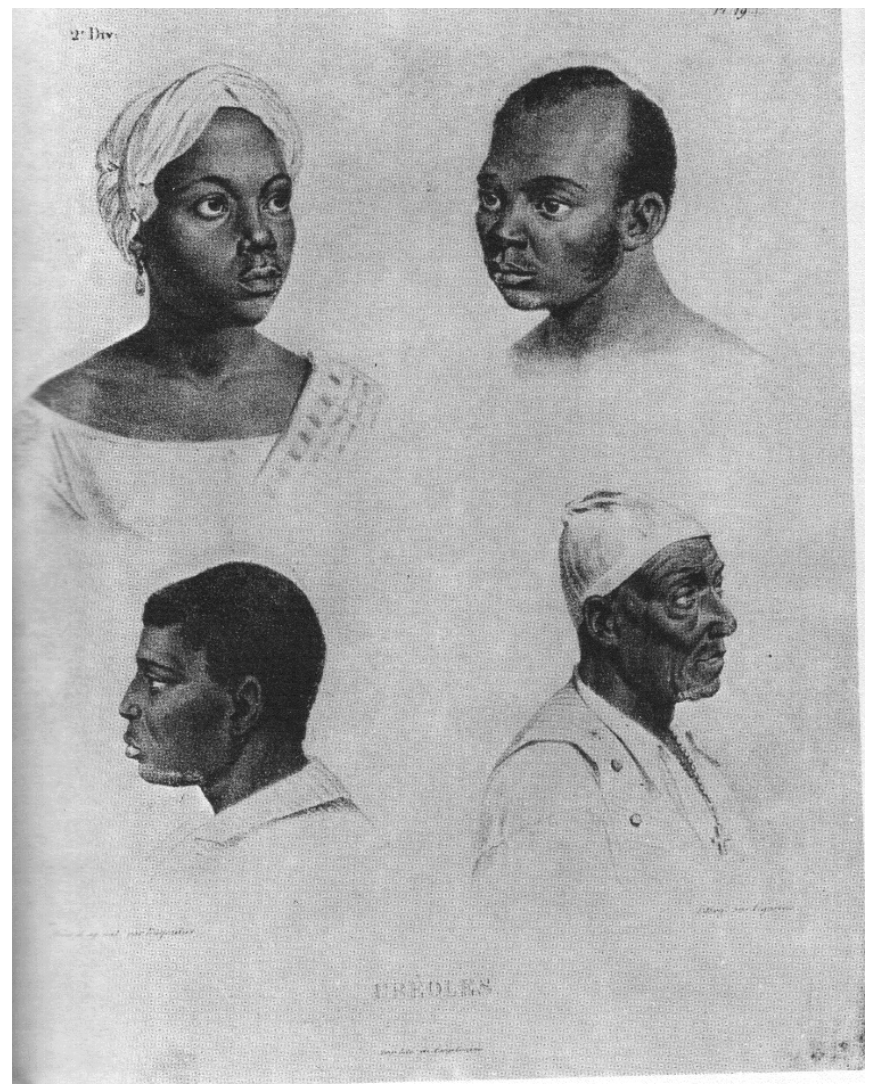

Fonte: Rugendas, Viagem pitoresca, s/d. 
(3) Negro Benguela, Angola, Congo, Monjolo

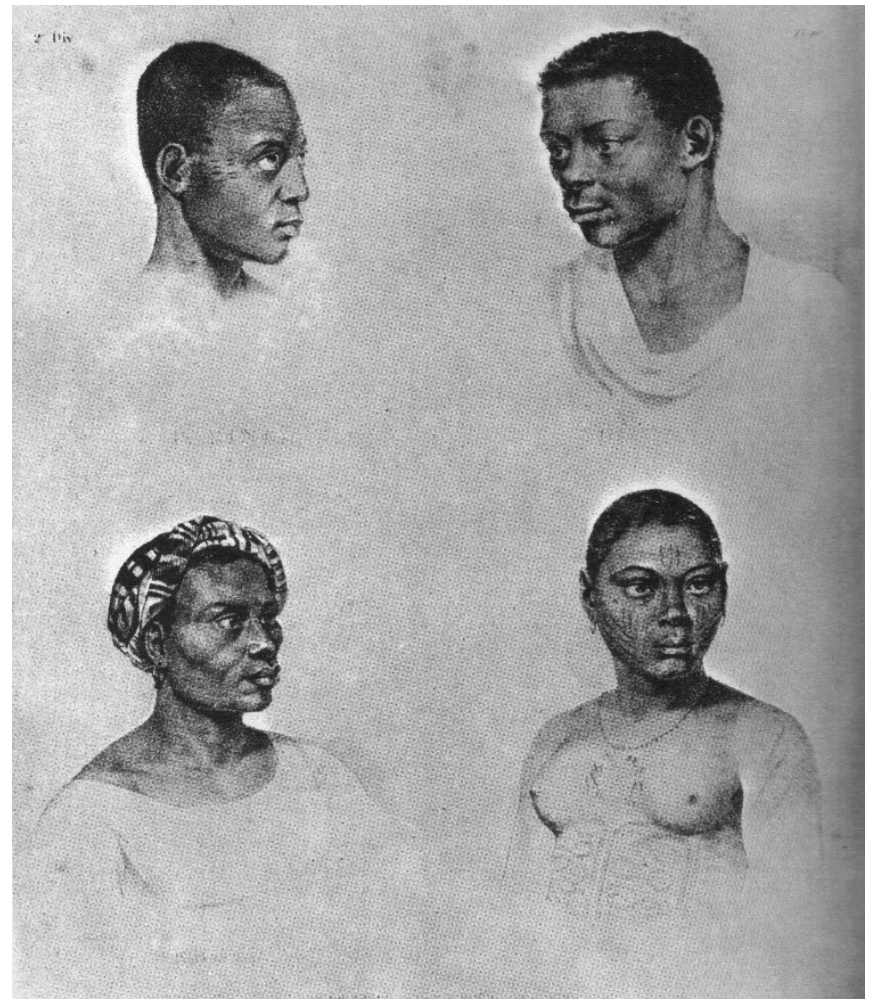

Fonte: Rugendas, Viagem pitoresca, s/d. 
(4) Negros crioulos também

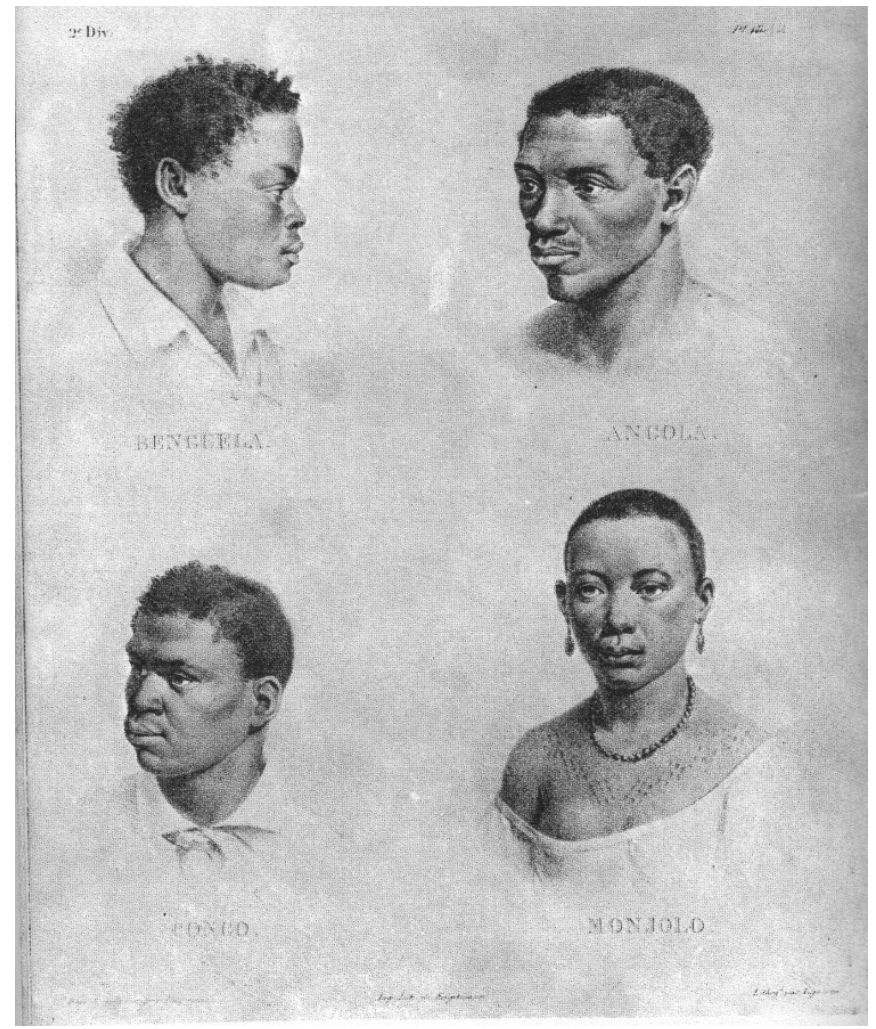

Fonte: Rugendas, Viagem pitoresca, s/d. 
(5) Cabeças de negros de diferentes nações

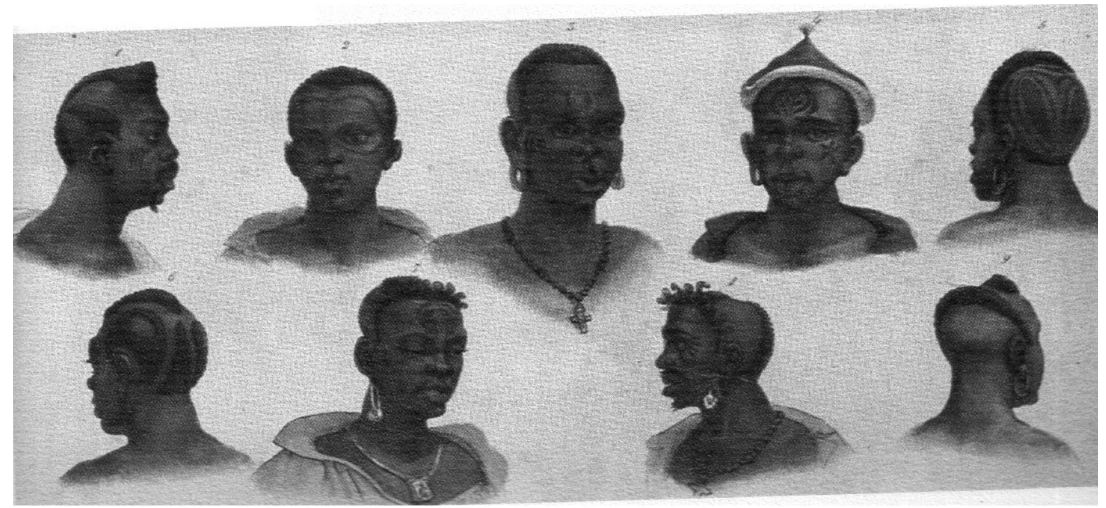

Fonte: Debret, Viagem pitoresca, 1989.

(6) Barbeiros Ambulantes

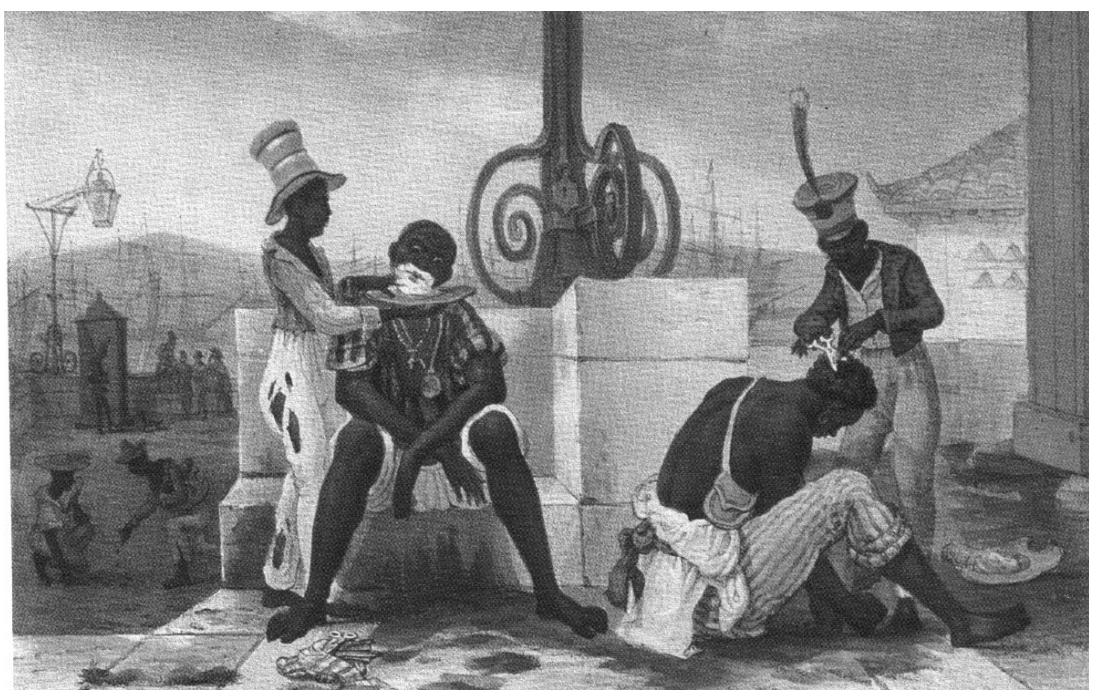

Fonte: Debret, Viagem pitoresca, 1989. 